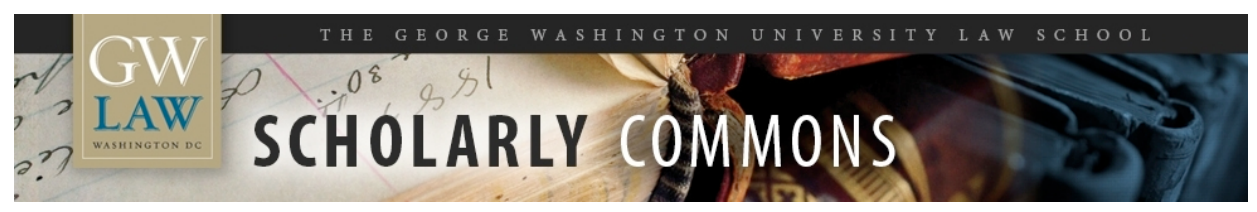

\title{
A Concise Guide to the Articles of Confederation as a Source for Determining the Original Meaning of the Constitution
}

\author{
Gregory E. Maggs \\ George Washington University Law School, gmaggs@law.gwu.edu
}

Follow this and additional works at: https://scholarship.law.gwu.edu/faculty_publications

Part of the Law Commons

\section{Recommended Citation}

Maggs, Gregory E., A Concise Guide to the Articles of Confederation as a Source for Determining the Original Meaning of the Constitution (2017). 85 Geo. Wash. L. Rev. 397 (2017); GWU Law School Public Law Research Paper No. 2017-18; GWU Legal Studies Research Paper No. 2017-18. Available at SSRN: http://ssrn.com/abstract $=2942259$

This Article is brought to you for free and open access by the Faculty Scholarship at Scholarly Commons. It has been accepted for inclusion in GW Law Faculty Publications \& Other Works by an authorized administrator of Scholarly Commons. For more information, please contact spagel@law.gwu.edu. 


\title{
A Concise Guide to the Articles of Confederation as a Source for Determining the Original Meaning of the Constitution
}

\author{
Gregory E. Maggs*
}

\begin{abstract}
Judges and scholars often refer to the Articles of Confederation when making claims about the original meaning of the United States Constitution. To help readers understand and evaluate such claims, this piece describes the formation and content of the Articles of Confederation and explains four ways in which the Articles may provide evidence of the original meaning of the Constitution. The two appendices to this piece contain an annotated copy of the Articles of Confederation and a table linking provisions of the Constitution to their antecedents in the Articles.
\end{abstract}

\section{TABle of Contents}

INTRODUCTION ..................................... 398

I. Overview of the Articles of Confederation ..... 401

A. The Continental and Confederation Congresses ..... 401

B. Key Sources for Research Concerning the Articles of Confederation .............................. 403

C. Description of the Articles of Confederation ....... 406

D. Drafting the Articles of Confederation ............ 409

E. Approval and Ratification..................... 411

F. Successes and Shortcomings.................. 414

G. Replacement by the Constitution ................ 417

II. Definitions of Original Meaning................ 418

III. Four Ways of Using the Articles of

Confederation to Make Claims About the

Original Meaning of the Constitution.......... 420

A. Claims Based on a Comparison of the Text of the

Constitution to the Text Used in the Articles of

Confederation ................................

* Professor of the Law, The George Washington University Law School. The Author thanks the Law School for its generous financial support and is grateful to his research assistant, Mr. Frank Chang, for improving the Article in many ways.

March 2017 Vol. 85 No. 2 
B. Claims Based on a Comparison of the Structure of Government Set Up by the Constitution to the Structure of the Government Established by the Articles of Confederation.........................

C. Claims Based on Extrinsic Evidence of the Framers' Goals in Replacing the Articles of Confederation with the Constitution ..........................

D. Claims Based on the Controversial Theory that the Constitution Did Not Fully Replace the Articles and that the Articles Therefore Continue to Supplement the Constitution .............................. 428

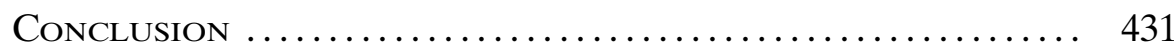

Appendix A: Annotated Articles of Confederation .... 432 Appendix B: Table of Constitutional Provisions and Related Provisions in the Articles of Confederation............................

\section{INTRODUCTION}

The Supreme Court has looked to the Articles of Confederation in more than 150 cases for guidance in determining the meaning of the Constitution. ${ }^{1}$ The most famous example appears in $\mathrm{McC}$ Culloch v. Maryland. ${ }^{2}$ In that case, the Court held that Congress has implied legislative powers based in part on a comparison of the text of the Tenth Amendment of the Constitution to the text of an antecedent provision in the Articles of Confederation. ${ }^{3}$ Writing for the Court, Chief Justice Marshall observed that while the Tenth Amendment limits Congress to those powers "delegated" to it by the Constitution, ${ }^{4}$ Article II of the Articles of Confederation previously had limited Congress to those powers "expressly delegated" by the Articles. ${ }^{5}$ Chief Justice Marshall concluded that omission of the word "expressly" indicated that the Framers intended the Constitution to include implied congressional powers. He reasoned: "The men who drew and adopted this amendment had experienced the embarrassments resulting from the insertion of this word in the articles of confederation, and probably omitted it to avoid those embarrassments."6

1 A Westlaw search of "articles of confederation" in the Supreme Court database yields 175 cases.

217 U.S. (4 Wheat.) 316 (1819).

3 Id. at $406-07$.

4 Id. at 406 (quoting U.S. Const. amend. X).

5 Id. (citing Articles of Confederation of 1781, art. II).

6 Id. at 406-07. 
More modern examples of similar reasoning are abundant. Members of the Supreme Court have cited the Articles of Confederation in ten constitutional cases since John Roberts became Chief Justice, including in major cases such as National Federation of Independent Business v. Sebelius, ${ }^{7}$ McDonald v. City of Chicago, ${ }^{8}$ and Arizona v. United States. ${ }^{9}$ Thousands of law review articles and hundreds of lower court opinions have also relied on the Articles of Confederation in addressing constitutional issues. ${ }^{10}$ The Articles of Confederation, indeed, now appear to have almost as much influence in efforts to determine the original meaning of the Constitution as other key sources such as the notes from the Constitutional Convention, the Federalist Papers, and the records of the state ratifying conventions.

Despite the significant role of the Articles of Confederation in constitutional interpretation, most lawyers and judges have received little instruction about them. They typically know that the Articles of Confederation set up a weak union whose shortcomings became apparent in the 1780s and led to adoption of the Constitution. But they usually do not study in greater detail the content of the Articles of Confederation or how their provisions relate to the Constitution. This brief Article seeks to address this situation by providing necessary information to those wishing to make or assess arguments about the original meaning of the Constitution that rely on the Articles of Confederation. This Article complements four other recent guides by the same Author addressing other sources of the original meaning. ${ }^{11}$

Part I provides an overview of the Articles of Confederation. It describes the Continental Congress and identifies key sources relating to the Articles. It also outlines the content of the Articles and then

7132 S. Ct. 2566, 2615 (2012) (Ginsburg, J., concurring in part and dissenting in part) (addressing the constitutionality of federal health care regulations under the Commerce Clause).

8561 U.S. 742, 819 (2010) (Thomas, J., concurring in part and concurring in judgment) (addressing the constitutionality of a municipal gun control law under the Second Amendment).

9132 S. Ct. 2492, 2511-12 (2012) (Scalia, J., concurring in part and concurring in judgment) (addressing constitutionality of state law restrictions on immigration under the Supremacy Clause).

10 A Westlaw search revealed 6046 law review articles and 1012 federal and state cases referencing the Articles of Confederation.

11 Gregory E. Maggs, A Concise Guide to the Federalist Papers as a Source of the Original Meaning of the United States Constitution, 87 B.U. L. Rev. 801 (2007); Gregory E. Maggs, A Concise Guide to the Records of the Federal Constitutional Convention of 1787 as a Source of the Original Meaning of the U.S. Constitution, 80 GEO. WASH. L. REV. 1707 (2012); Gregory E. Maggs, A Concise Guide to the Records of the State Ratifying Conventions as a Source of the Original Meaning of the U.S. Constitution, 2009 U. ILL. L. Rev. 457 (2009); Gregory E. Maggs, A Concise Guide to Using Dictionaries from the Founding Era to Determine the Original Meaning of the Constitution, 82 Geo. WAsh. L. Rev. 358 (2014). 
describes their drafting and ratification. It further discusses the exceptional achievements and failures of the government created by the Articles of Confederation.

Part II discusses different definitions of original meaning.

Part III then critically examines four types of claims about the original meaning of the Constitution that rely in one way or another on the Articles of Confederation. These include:

claims based on a comparison of the language of the Constitution to the language of the Articles of Confederation;

claims based on a comparison of the structure of the government set up by the Constitution to the structure of the government established by the Articles of Confederation;

claims based on extrinsic evidence of the Framers' goals in replacing the Articles of Confederation with the Constitution; and

claims based on the controversial theory that the Constitution did not fully replace the Articles of Confederation and that the Articles therefore continue to supplement the Constitution.

As this Article will show with specific examples from Supreme Court decisions, each type of claim has certain strengths and weaknesses. Knowing these strengths and weaknesses may help writers bolster their own claims about the original meaning that rely on the Articles of Confederation and assess such claims when made by others.

Appendix A contains an annotated copy of the Articles of Confederation. Appendix B presents a table showing current constitutional provisions and their antecedents in the Articles of Confederation.

Before going further, one additional preliminary point requires mention. Although this Article discusses how the Articles of Confederation might be used as a source for understanding the original meaning of the Constitution, it takes no position on whether or to what extent courts must follow the original meaning. That is an interesting and important question that other works address. ${ }^{12}$ Suffice it to say that researchers may want to know more about the original meaning of the Constitution even if they do not believe that the original meaning should necessarily dictate the answers to modern constitutional issues.

12 See, e.g., Gregory E. Maggs \& Peter J. Smith, Constitutional Law: A ContemPORARy APPROACH 13-18 (3d ed. 2015). 


\section{Overview of the Articles of Confederation}

\section{A. The Continental and Confederation Congresses}

In the 1760s and 1770s, an important question arose about whether the Parliament of the United Kingdom had power to impose taxes on the American colonies. The passage of the Customs Act (or "Tea Act") of 1772 was a key event in this controversy. The Tea Act went into effect on May 10, 1773. ${ }^{13}$ This Act required Americans to pay a duty on all imported tea. ${ }^{14}$ The tax was not large, and Parliament in fact simultaneously subsidized the cost of tea by eliminating export duties on tea shipped from Great Britain. ${ }^{15}$ Through the Act, Parliament apparently hoped to achieve American acquiescence to taxation.

On December 16, 1773, opponents of the Tea Act staged the socalled "Boston Tea Party" as a protest. ${ }^{16}$ They took tea belonging to the British East India Company and threw it into Boston Harbor, thus preventing its sale and the collection of any tax. ${ }^{17}$ Parliament responded by passing five acts in early 1774 that were designed to punish Massachusetts and keep other colonies in check. ${ }^{18}$ These laws were called the "Coercive Acts" in Great Britain and the "Intolerable Acts" in America. ${ }^{19}$ Among other things, the Intolerable Acts closed the Port of Boston, ${ }^{20}$ lessened the autonomy of the government of

13 The Customs Act, 13 Geo. 3 c. 44 (Eng.), reprinted in 30 The Statutes at Large 74

(Danby Pickering ed. 1773) (also known as the Tea Act).

14 See id. pt. II, at 76 (imposing a duty of $£ 4$ for every tub or chest of tea).

15 See id. pt. I, at 74-75 ("draw[ing] back" any duties for export of teas to any British colonies in America).

16 The Port of Boston Act 1774, 14 Geo. 3 c. 12, pmbl. (Eng.), reprinted in 30 The STATutes at Large 335 (Danby Pickering ed. 1773) (describing the Boston Tea Party); see also Boston Tea Party, Encyclopaedia Britannica, https://www.britannica.com/event/Boston-TeaParty (last updated Feb. 2, 2007).

17 The Port of Boston Act 1774, pmbl., at 335.

18 See, e.g., The Administration of Justice Act 1774, 14 Geo. 3 c. 39, § V (Eng.), reprinted in 30 The Statutes at Large 370 (Danby Pickering ed. 1773); The Port of Boston Act 1774 $\S$ I, at 336-37; The Massachusetts Government Act 1774, 14 Geo. 3 c. 45, § I (Eng.), reprinted in 30 The Statutes at Large 382 (Danby Pickering ed. 1773).

19 Intolerable Acts, EnCYClOPAEDiA BRITANniCA, https://www.britannica.com/event/Intolerable-Acts (last updated Apr. 1, 2015).

20 The Port of Boston Act $1774 \S$ I, at 336-37 (providing that "it shall not be lawful for any person or persons whatsoever to lade put, or cause or procure to be laden or put, off or from any quay, wharf, or other place, within the said town of Boston"). 
Massachusetts, ${ }^{21}$ and provided that British officials could be tried in England, rather than Massachusetts, if accused of crimes. ${ }^{22}$

The Intolerable Acts prompted Rhode Island, Pennsylvania, New York, and Massachusetts to call for the colonies to hold an assembly which became known as the First Continental Congress. ${ }^{23}$ The First Continental Congress met from September 5, 1774 to October 26, 1774. ${ }^{24}$ At its conclusion, the First Continental Congress called for a Second Continental Congress to meet the following spring. ${ }^{25}$ In the interim, fighting broke out in Massachusetts when British forces unsuccessfully raided the towns of Lexington and Concord in April 1775. ${ }^{26}$ The Second Continental Congress convened on May 10, 1775 and continued meeting until March 2, 1781.27 During this time, Congress directed the fighting of the Revolutionary War, declared independence from the United Kingdom, and established the Articles of Confederation.

In his eighteenth-century Dictionary of the English Language, Samuel Johnson defined a "confederation" as a "league" or "alliance." 28 This definition accurately captures the essential nature of what the Articles of Confederation established among the thirteen North American colonies that had declared their independence from the United Kingdom in July 1776. The Articles of Confederation were not

21 The Massachusetts Government Act 1774 I , at 382 (providing that "the charter, granted by their majesties King William and Queen Mary to the inhabitants of the said province of the Massachusetts's Bay . . . and all and every clause, matter, and thing, therein contained, which relates to the time and manner of electing the assistants or counsellors for the said province, be revoked, and is hereby revoked and made void and of none effect").

22 The Administration of Justice Act $1774 \S \mathrm{V}$, at 370 (providing that an official indicted for "murder, or other capital crime" allegedly committed during "suppression of riots, or in the support of the laws of revenue, or in acting in his duty as an officer of revenue ... may be tried in some other of his Majesty's colonies, or in Great Britain").

23 See Office of the Historian, Bureau of Pub. Affairs, Continental Congress, 1774-1781, U.S. DeP'T of StATE, https://history.state.gov/milestones/1776-1783/continental-congress (last visited Dec. 23, 2016).

24 See Journals of the Continental Congress, LiBR. OF CONGREss, http://memory.loc.gov/ ammem/amlaw/lwjc.html (last visited Dec. 23, 2016).

25 See 1 Journals of the Continental Congress 1774-1789, at 102 (Worthington Chauncey Ford ed., 1904) ("Resolved, as the Opinion of this Congress, that it will be necessary, that another Congress should be held on the tenth day of May next . . .").

26 See Battles of Lexington and Concord, Encyclopaedia Britannica, https:// www.britannica.com/event/Battles-of-Lexington-and-Concord (last updated Aug. 12, 2010).

27 See Libr. of Congress, supra note 24.

28 Confederation, Samuel Johnson, A Dictionary of the English Language (London, J.F. \& C. Rivington et al., 10th ed. 1792). 
so much a constitution as a mutual defense treaty establishing a "firm league of friendship" among newly-formed, co-equal states. ${ }^{29}$

The drafting of the Articles of Confederation took place between July 1775 and November $1777 .{ }^{30}$ The subsequent state ratification process was slow; the Articles were not ratified until March 1, 1781. ${ }^{31}$ When Congress reconvened on March 2, 1781, it called itself "the United States in Congress Assembled." 32 Subsequently, many historians have referred to this body as the "Congress of the Confederation" or "Confederation Congress" (although others still refer to it as the "Continental Congress"). ${ }^{33}$ The Confederation Congress met from March 2, 1781 until March 4, 1789, when the federal government under the Constitution took over. ${ }^{34}$ Although the Articles of Confederation did not remain in effect for a long period, experience under the Articles paved the way for creating the far more enduring Constitution. ${ }^{35}$ As the subsequent discussion shows, the influence of the Articles of Confederation remains discernable to this day.

\section{B. Key Sources for Research Concerning the Articles of Confederation}

Researchers who are interested in discerning how the Articles of Confederation may provide evidence of the original meaning of the Constitution generally should start with a careful examination of the text of the Articles. Appendix A contains an annotated copy of the complete document, which is considerably shorter than the Constitution. The annotations explain difficult passages and link most of the provisions to analogues in the Constitution. Appendix B contains a table of constitutional provisions that have antecedents in the Articles of Confederation.

29 Articles of Confederation of 1781, art. III.

30 See 5 Journals of the Continental Congress 1774-1789, at 432 (Worthington Chauncey Ford ed., 1906); see also Office of the Historian, Bureau of Pub. Affairs, Articles of Confederation, 1777-1781, U.S. DeP'T OF STATE, https://history.state.gov/milestones/1776-1783/ articles (last visited Dec. 23, 2016).

31 See 19 Journals of the Continental Congress 1774-1789, at 223 (Gaillard Hunt ed., 1912).

32 Id.

33 Congress of the Confederation, Black's Law Dictionary (10th ed. 2014).

34 See 19 Journals of the Continental Congress 1774-1789, supra note 31, at 223; 34 Journals of the Continental Congress 1774-1789, at 605 (Roscoe R. Hill ed., 1937) (final entry of the Journal of the Continental Congress on March 2, 1789).

351 Francis Newton Thorpe, The Constitutional History of the United States 280-88 (1901). 
After the text of the Articles of the Confederation, the best primary source for understanding the Articles is the thirty-four-volume collection of the Journals of the Continental Congress, which is now available for free online. ${ }^{36}$ Carefully compiled, edited, and published by the Library of Congress between 1904 and 1937, the Journals contain all of the records-including formerly secret portions of the records - that the Continental Congress kept from September 5, 1774 until March 2, 1789. ${ }^{37}$ These records reveal substantial information about the drafting of the Articles, beginning with Benjamin Franklin's early draft in July $1775,{ }^{38}$ and ending with the final version completed in November $1777 . .^{39}$ They also show how and why the state approval and ratification process dragged from November 1777 to March 1781.40 The records further reveal important details about how Congress functioned both before and after ratification, and the call for the Constitutional Convention and the replacement of the Articles of Confederation with the new Constitution.

In addition to providing specific details about the Articles of Confederation, perusing the Journals places the whole subject in context by revealing the extraordinary military, financial, diplomatic, and political exigencies that the Continental Congress had to address. For example, on June 12, 1776, the same day that the Continental Congress created a committee to draft the Articles of Confederation, it approved a resolution that "General Washington be directed to order the riffles of such men belonging to the riffle regiments as will not reinlist, to be purchased." ${ }^{41}$ On November 15, 1777, the day Congress approved the text of the Articles of Confederation for submission to the states, they also dealt with General Washington's increasingly urgent call "to send, without delay, to the army under his command, the blankets and other articles of cloathing" that had previously been requested and would be desperately needed during the bitter winter the Army spent in Valley Forge. ${ }^{42}$ On March 2, 1781, in the first session following ratification of the Articles, Congress took up the news that

\footnotetext{
36 LiBr. OF CONGRESS, supra note 24.

37 Id.

382 Journals of the Continental Congress 1774-1789, at 195-99 (Worthington Chauncey Ford ed., 1905).

399 Journals of the Continental Congress 1774-1789, at 907-25 (Worthington Chauncey Ford ed., 1907).

40 See generally 2 Journals of the Continental Congress 1774-1789, supra note 38; 9 Journals of the Continental Congress 1774-1789, supra note 39.

415 Journals of the Continental Congress 1774-1789, supra note 30, at 432.

429 Journals of the Continental Congress 1774-1789, supra note 39, at 906-07.
} 
Henry Laurens, who had been the President of the Continental Congress from November 1, 1777 to December 9, 1778, was "taken upon the high seas, instead of being treated as a Prisoner of War, was sent to the Tower of London, put into close confinement, and by the tenor of his commitment is pretended to be considered as a traitorous subject of the King of Great Britain." 43 And on February 20, 1787, the day before Congress called for the assembly that became the Constitutional Convention, the members were greatly concerned with conflicts with Indian tribes. ${ }^{44}$ Congress resolved that

the Secretary at War be, and he is hereby directed to take order for immediately posting the Troops now in the Western Country at such places, as most effectually under circumstances to protect the Inhabitants, on the Western frontier of Pennsylvania and Virginia from incursions and depredations of the Savages. ${ }^{45}$

The classic secondary source for understanding the creation of the Articles of Confederation, the United States's experience under the Articles, and the Articles' ultimate failure is Francis Newton Thorpe's The Constitutional History of the United States (available for free online) ${ }^{46}$ Another fine work, cited in eight Supreme Court cases, is Merrill Jensen's The Articles of Confederation: An Interpretation of the Social-Constitutional History of the American Revolution, 1774-1781. ${ }^{47}$ Numerous law review articles also helpfully address specific questions about the relationship of the Articles of Confederation to the Constitution. ${ }^{48}$

4319 Journals of the Continental Congress 1774-1789, supra note 31, at 227; see also U.S. Cong., LAURENS, Henry, 1724-1792, Biographical Directory of the U.S. ConGRESS, http://bioguide.congress.gov/scripts/guidedisplay.pl?index=L000121 (last visited Dec. 20, 2016).

4432 Journals of the Continental Congress 1774-1789, at 69 (Roscoe R. Hill ed., 1936).

45 Id.

46 See generally 1 ThORPe, supra note 35, at 208-88.

47 Merrill Jensen, The Articles of Confederation: An Interpretation of the Social-Constitutional History of the American Revolution, 1774-1781 (1959).

48 See, e.g., Eric M. Freedman, Why Constitutional Lawyers and Historians Should Take a Fresh Look at the Emergence of the Constitution from the Confederation Period: The Case of the Drafting of the Articles of Confederation, 60 TenN. L. Rev. 783, 784 (1993); Vasan Kesavan, When Did the Articles of Confederation Cease to Be Law?, 78 Notre Dame L. Rev. 35 (2002); Douglas G. Smith, An Analysis of Two Federal Structures: The Articles of Confederation and the Constitution, 34 SAn Diego L. Rev. 249, 255-56 (1997). 


\section{Description of the Articles of Confederation}

Articles I, II, and III of the Articles of Confederation concerned the nature of the Confederacy. They announced that it would be called "The United States of America," 49 but emphasized that each state would retain its own "sovereignty, freedom and independence" 50 and every power not "expressly delegated" to Congress. ${ }^{51}$ They further committed the states to a common defense, "binding themselves to assist each other, against all force offered to, or attacks made upon them, or any of them." ${ }^{2}$

Articles IV, V, VI, VII, and IX addressed domestic and foreign relations and military matters. They specified that no state could deny the "privileges and immunities" of citizens of other states and required the states to allow freedom of movement. ${ }^{53}$ They gave each state one vote in Congress. ${ }^{54}$ They further specified that only Congress, not the states, could engage in foreign diplomacy, enter treaties, receive ambassadors, and declare war. ${ }^{55}$ They described how states would raise military forces and authorized the state legislatures to appoint military officers below the rank of colonel. ${ }^{56}$ They also provided that Congress would resolve disputes among the states..$^{57}$

Articles VIII and XII concerned the finances of the Confederation. They provided that the United States would pay expenditures from funds contributed by state legislatures and that states would contribute in proportion to the value of the real property located within their territories. ${ }^{58}$ These provisions also reaffirmed any debts incurred before the effective date of the Articles of Confederation. ${ }^{59}$

Article $\mathrm{X}$ authorized a committee of the states to make certain decisions and take certain administrative actions when Congress was not in session. ${ }^{60}$ Article XI provided for admission of Canada to enter the confederation. ${ }^{61}$ Article XIII required the states to comply with the Acts of Congress, declared the union of the states to be perpetual,

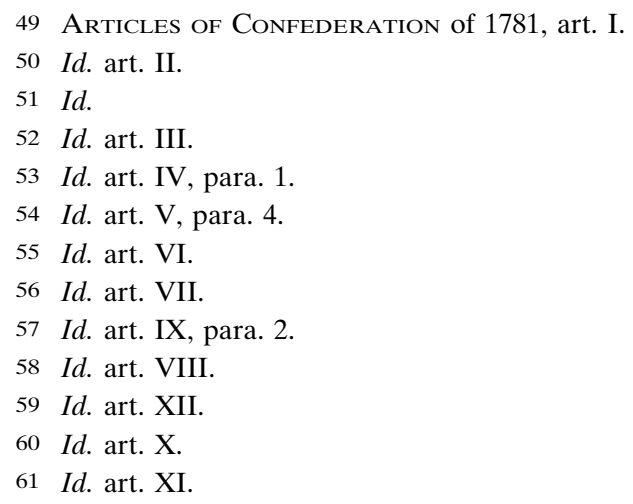


and specified that any changes to the Articles of Confederation would require approval of Congress and ratification by all the states. ${ }^{62}$

Notably absent from the Articles of Confederation is any provision for a separate executive branch of government. Congress, accordingly, had to make executive decisions itself. For example, in perusing the Journals of the Continental Congress, it is common to see Congress considering resolutions on topics such as whether "to order the party of Colonel Bland's regiment of light dragoons now at Charlotteville, to proceed to South Carolina forthwith and join the regiment there" 63 and whether "to send Mr. Carmichael to the Court of Portugal in pursuance of the resolution of the 11th day of July, 1781, [provided] he shall have good grounds to expect that such a measure will attain the object proposed by the Superintendant of Finance." ${ }^{64}$ But it would be an overstatement to say the United States had no "executive" agencies or officials. Because Congress could not carry out all of its decisions without assistance, it created what are now called executive departments. These included, among other bodies, a Board of Treasury, a Board of War, a Board of Admiralty, and a Department of Foreign Affairs, all of which compiled records that still exist. ${ }^{65}$

The Articles of Confederation also did not create a general national court system as the United States has today. But the Articles did provide for the appointment of specialized courts for "trial of piracies and felonies committed on the high seas" and "cases of captures." ${ }^{66}$ It further allowed Congress to create courts to hear cases between states concerning "boundary, jurisdiction, or any other causes," and it designated Congress as "the last resort on appeal" in all such cases. ${ }^{67}$ The Constitution now gives these roles to the U.S. Supreme Court. ${ }^{68}$

The Articles of Confederation delegated a number of strong powers to the Confederation Congress. As under the current Constitution, Congress had sole power, exclusive of the states, to declare war, send

62 Id. art. XIII.

6315 Journals of the Continental Congress 1774-1789, at 1367 (Worthington Chauncey Ford ed., 1909).

6422 Journals of the Continental Congress 1774-1789, at 250 (Gaillard Hunt ed., 1914).

65 Records of the Continental and Confederation Congresses and the Constitutional Convention, NAtional ARChives, http:/www.archives.gov/research/guide-fed-records/groups/ 360.html\#360.4 (last updated Aug. 15, 2016) (identifying the existing collections of the records from these different boards).

66 Articles of Confederation of 1781, art. IX.

67 Id.

68 U.S. Const. art. III, § 2, cls. 1-2. 
and receive ambassadors, make treaties, and prohibit exportation and importation of goods, and grant letters of marque and reprisal. ${ }^{69}$ Congress also could borrow and spend money, a power which it exercised in great measure. ${ }^{70}$ When the new federal government took over in 1789, the Continental and Confederation Congresses had already amassed a national debt of more than $\$ 70$ million. ${ }^{71}$ Congress also had power to build an Army and Navy ${ }^{72}$ which it used successfully to defeat the United Kingdom, the world's greatest military power.

But the Confederation Congress lacked two key powers. No provision gave Congress power to regulate commerce, a power which was left to the states themselves. Congress also could not directly impose taxes. Instead, the revenue of the United States was to be "supplied by the several states, in proportion to the value of all land within each state." 73 And the "taxes for paying that proportion" were to be "levied by the authority and direction of the legislatures of the several states." 74 The states routinely failed to meet their obligations. Congress had no options other than to "remind the states" of the necessity of making payments or to excuse the debts..$^{75}$ On April 24, 1784, a report to Congress lamented: "The requisitions of October 30, 1781, for eight millions of dollars, and of October 16, 1782, for two millions of dollars, have been so partially complied with, and in such unequal proportions, that Congress can retain no hopes of their full execution." 76

The Articles of Confederation contained no Bill of Rights. During the drafting of the Articles, no member proposed one. ${ }^{77}$ Historian Francis Newton Thorpe suggests the drafters may have thought that Congress would have such limited powers that it could not take actions which would violate individual rights. ${ }^{78}$

The Articles of Confederation is considerably shorter than the Constitution, having only 3400 words as compared to the Constitution's 4500 words (excluding the constitutional amendments). But at

69 See Articles of Confederation of 1781, art. IX.

70 Id.

71 Our History, U.S. DEP'T OF TREASURY, https://www.treasurydirect.gov/govt/reports/pd/ histdebt/histdebt_ourheritage.htm (last updated Apr. 29, 2014).

72 Articles of Confederation of 1781, art. IX.

73 Id. art. VIII.

74 Id.

7526 Journals of the Continental Congress 1774-1789, at 299 (Gaillard Hunt ed., 1928).

76 Id.

77 See 1 ThORpe, supra note 35, at 232.

78 See id. 
the same time, the Articles of Confederation are more verbose, in some respects. The document covers fewer subjects but treats them in greater detail and, generally, with less eloquence. Article XIII provided that the Articles could be altered if "such alteration be agreed to in a congress of the united states, and be afterwards con-firmed by the legislatures of every state," but no amendments were ever made. ${ }^{79}$ When Congress called for a convention to consider amendments on February $21,1787,{ }^{80}$ this convention quickly changed course, drafting and reporting a completely new Constitution to replace the Articles of Confederation. ${ }^{81}$

\section{Drafting the Articles of Confederation}

The Journals of the Continental Congress document the drafting of the Articles of Confederation. As noted above, the Second Continental Congress began meeting in May of 1775, shortly after the fighting began in Boston. ${ }^{82}$ Although the United States did not declare independence until more than a year later, Benjamin Franklin very early on foresaw the direction that the conflict was heading. On his own initiative, he drew up proposed "Articles of Confederation," which he presented on July $21,1775 .{ }^{83}$

Congress, however, did not act on Franklin's proposal immediately. Instead, the impetus for forming a confederation came on June 11, 1776, when James Randolph proposed that the Continental Congress declare its independence from the United Kingdom. ${ }^{84}$ Congress immediately appointed a committee to draft this declaration consisting of Thomas Jefferson, Samuel Adams, Benjamin Franklin, Roger Sherman, and Robert Livingston ${ }^{85}$ At this point, Congress realized that if the colonies did become independent, they would need to work out some kind of new legal arrangement to keep them aligned with each other and to establish foreign relations with other nations. Accordingly, on the same day, Congress resolved "that a committee be appointed to prepare and digest the form of a confederation to be entered into between these colonies." ${ }^{86}$

79 Articles of Confederation of 1781, art. XIII.

8032 Journals of the Continental Congress 1774-1789, supra note 44, at 73-74.

81 See Maggs, A Concise Guide to the Records of the Federal Constitutional Convention, supra note 11 , at 1711 .

82 See supra note 27 and accompanying text.

832 Journals of the Continental Congress 1774-1789, supra note 38, at 195-99.

845 Journals of the Continental Congress 1774-1789, supra note 41, at 431.

85 Id.

86 Id. 
The committee to draft the Articles of Confederation was formed the following day, on June 12, $1776 .{ }^{87}$ The committee was to consist of one member from each "colony"-a word soon to be replaced with "state." 88 The initial committee included John Dickinson, Samuel Adams, Roger Sherman, and other luminaries of the era. ${ }^{89}$ The committee did not include Benjamin Franklin, presumably because he was busy with the Declaration of Independence. The committee, however, incorporated many of Franklin's ideas from the draft he had prepared the previous year..$^{90}$

On July 12, 1776, the drafting committee presented a draft of the Articles of Confederation to the Continental Congress. ${ }^{91}$ The manuscript was handwritten by John Dickinson. ${ }^{92}$ This draft contained twenty articles and was similar in many ways to the final version of the Articles discussed above. ${ }^{93}$ The limited nature of the proposed Confederation is typified by emphatic statements like "the United States assembled shall never impose or levy any Taxes or Duties, except in managing the Post-Office ...."94

Congress did not immediately discuss the draft of the Articles of Confederation, but instead ordered copies to be printed for subsequent discussion. ${ }^{95}$ Starting on July 22, 1776, and on selected days afterward, Congress began meeting as a committee of the whole to address the Articles. ${ }^{96}$ Because these were not formal sessions, official records were not kept. But notes taken by John Adams and Thomas Jefferson describe some of what occurred during these sessions. ${ }^{97}$

Perhaps the two most controversial topics discussed were how the Confederation would make decisions and how it would raise money from the states. Congress ultimately decided that each state would have one vote and that each state would contribute money according to the total value of the property located in the state..$^{98}$ According to

87 See id. at 433.

88 Id.

89 Id.

90 Id. at 545, 546 \& n.1; 2 Journals of the Continental Congress 1774-1789, supra note 38, at 195-99 (Franklin's “Articles of Confederation”).

915 Journals of the Continental Congress, supra note 41, at 546.

92 Id. at 546-54 (reprinting the draft).

93 Id.

$94 I d$. at 552 (portion of the proposed article XVIII).

$95 \mathrm{Id}$. at 555.

$96 I d$. at 600.

976 Journals of the Continental Congress 1774-1789, at 1069-83 (Worthington Chauncey Ford ed., 1906) (notes of John Adams); id. at 1085-1106 (notes of Thomas Jefferson). 989 Journals of the Continental Congress 1774-1789, supra note 39, at 910, 913-14. 
notes taken by John Adams, on July 30, 1776, Franklin presciently argued that this formula was a recipe for failure: "Let the smaller Colonies give equal money and men, and then have an equal vote. But if they have an equal vote without bearing equal burthens, a confederation upon such iniquitous principles will never last long." ${ }_{99}$ Franklin proposed that the Articles of Confederation should provide for the states to vote "in proportion to numbers," but this proposal failed. ${ }^{100}$ In discussions of that suggested alternative, one difficulty that arose was how to count slaves. ${ }^{101}$ Benjamin Harrison V, a delegate from Virginia and the father of President William Henry Harrison and greatgrandfather of President Benjamin Harrison, "proposed a compromise, that two slaves should be counted as one freeman"-presaging the similar three-fifths compromise that later marred the Constitution. ${ }^{102}$ But Congress did not change the rule that each state would have one vote. ${ }^{103}$

\section{E. Approval and Ratification}

Despite the importance of formally uniting the states, Congress was extremely busy with the conduct of the Revolutionary War and could not devote its full attention to the proposed draft of the Articles of Confederation. ${ }^{104}$ Debates and discussions on the subject took place from time to time until Congress ultimately approved the final version of the Articles on November 15, 1777. ${ }^{105}$ Because the Articles of Confederation were like a multilateral treaty, before they could go into effect, each of the thirteen state legislatures had vote to approve them and then formally ratify them. ${ }^{106}$

Congress sent a copy of the Articles to each state together with a letter urging their approval. ${ }^{107}$ The drafters knew that the Articles were not perfect, but they stressed that they were about the best that the states could hope for under the circumstances. ${ }^{108}$ Congress explained that "progress [had] been attended with uncommon embar-

\footnotetext{
99 Id. at 1079.

100 Id. at 1081.

101 Id. at $1099-1100$.

102 Id. at 1100 (notes of Thomas Jefferson); see also U.S. Cong., HARRISON, Benjamin,
} (1726-1791), Biographical Directory of the U.S. Congress, http://bioguide.congress.gov/ scripts/biodisplay.pl?index=H000262 (last visited Dec. 26, 2016).

1039 Journals of the Continental Congress 1774-1789, supra note 39, at 910.

104 See Freedman, supra note 48, at 799-800.

1059 Journals of the Continental Congress 1774-1789, supra note 39, at 906-07.

106 See id. at 925.

107 Id. at $932-34$.

108 See id. at 933. 
rassments and delay." ${ }^{109}$ In its letter, Congress cited the difficulty of having to prepare provisions "accommodated to the opinion and wishes of the delegates of so many states, differing in habits, produce, commerce, and internal police." 110 Congress also stressed to the states that forming a union would "confound our foreign enemies, defeat the flagitious practices of the disaffected, strengthen and confirm our friends, support our public credit, restore the value of our money, enable us to maintain our fleets and armies, and add weight and respect to our councils at home, and to our treaties abroad." 111 Table 1 details the timeline of when the legislatures of each state approved and ratified the Articles of Confederation.

Table 1. Approval and Ratification of the Articles of CONFEDERATION

\begin{tabular}{|c|c|c|}
\hline State & Legislature Approved & Ratified \\
\hline Virginia & December 16, 1777 & July 9,1778 \\
\hline South Carolina & February 5, 1778 & July 9,1778 \\
\hline New York & February 6,1778 & July 9,1778 \\
\hline Rhode Island & February 9,1778 & July 9,1778 \\
\hline Connecticut & February 12,1778 & July 9,1778 \\
\hline New Hampshire & March 4, 1778 & July 9,1778 \\
\hline Pennsylvania & March 5, 1778 & July 9,1778 \\
\hline Massachusetts & March 10, 1778 & July 9,1778 \\
\hline North Carolina & April 5, 1778 & July 21,1778 \\
\hline Georgia & February 26,1778 & July 24,1778 \\
\hline New Jersey & November 19,1778 & November 26,1778 \\
\hline Delaware & February 1,1779 & February 1,1779 \\
\hline Maryland & February 2, 1781 & March 1, 1781 \\
\hline
\end{tabular}

Nine state legislatures-all except New Jersey, Delaware, and Maryland-took heed of Congress's urging and quickly considered, approved, and authorized their delegates to ratify the Articles of Confederation. ${ }^{112}$ Ratification took place in Congress, with delegates from these states signing a parchment on which the Articles were engrossed. ${ }^{113}$ Delegates from New Hampshire, Massachusetts, Rhode Island, Connecticut, New York, Pennsylvania, Virginia, and South

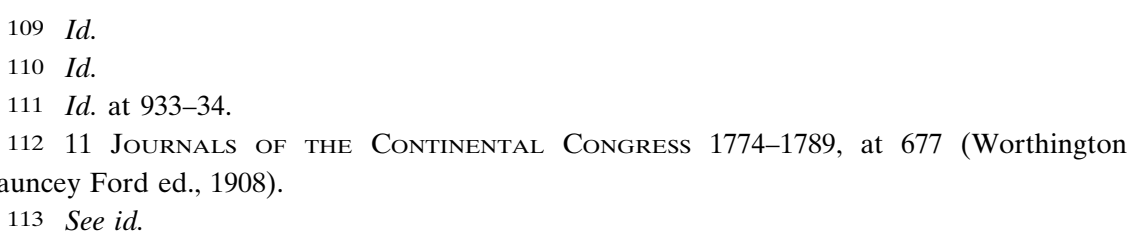


Carolina signed the document on July 9, 1778. ${ }^{114}$ The delegates from North Carolina and Georgia were absent that day but signed on July 21 and July 24 respectively. ${ }^{115}$

This left only New Jersey, Delaware, and Maryland. Their delegates informed Congress that their state legislatures had not approved the Articles of Confederation because they were concerned about claims that several of the other states were making to land to the west. ${ }^{116}$ In particular, New York, Virginia, Massachusetts, Connecticut, North Carolina, South Carolina, and Georgia all asserted far-reaching boundaries based on their original charters. ${ }^{117}$ The other states did not have such claims and were concerned that they might later be dwarfed in size. ${ }^{118}$

Despite these concerns, New Jersey approved the Articles of Confederation on November 26, 1778, ${ }^{119}$ and Delaware approved them on May 5, 1779. ${ }^{120}$ This left Maryland as the sole holdout, and it did not approve the Articles of Confederation until February 2, 1781.121 Although the other states' territorial claims were not fully resolved by that time, steps toward compromise occurred. The New York legislature passed a law on February 19, 1780, agreeing to settle the western boundary and cede the western lands to the United States. ${ }^{122}$ Similarly, Connecticut conditionally offered to relinquish its claims to western lands on October 10, 1780.123 And when Maryland ultimately did give approval, it expressly asserted a claim to a proportionate share of the "back country." 124

Those who worked on the drafting and ratification of the Articles of Confederation undoubtedly learned important lessons in nationbuilding. Benjamin Franklin and five of the men who signed the

114 See id.

115 Id. at $677,709,716$.

116 See id. at 677; see also 1 Thorpe, supra note 35, at 229; Peter A. Appel, The Power of Congress "Without Limitation": The Property Clause and Federal Regulation of Private Property, 86 Minn. L. Rev. 1, 16-17 (2001).

117 See 1 ThORPe, supra note 35, at 229-30, $230 \mathrm{n} .1$ (summarizing these claims and what ultimately happened with respect to them).

118 See id.

11912 Journals of the Continental Congress 1774-1789, at 1164 (Worthington Chauncey Ford ed., 1908).

12014 Journals of the Continental Congress 1774-1789, at 548 (Worthington Chauncey Ford, ed., 1909).

121 Journals of the Continental Congress 1774-1789, supra note 31, at 213-14.

1223 John Bach McMaster, A History of the People of the United States, From the Revolution to the Civil War 95 (1921).

12312 Register of Debates in Congress 1334 (1836).

12419 Journals of the Continental Congress 1774-1789, supra note 31, at 139. 
Articles of Confederation on behalf of the ratifying states later participated in the Constitutional Convention: Daniel Carroll (Maryland), John Dickinson (Delaware), Gouverneur Morris (New York), Robert Morris (Pennsylvania), and Roger Sherman (Connecticut). ${ }^{125}$

\section{F. Successes and Shortcomings}

The ratification of the Articles of Confederation in March 1781 did not dramatically alter the conduct of Congress. Congress had not been waiting patiently for a formal union to get started with the business of governing. On the contrary, it had been actively directing the conduct of the war since 1775. ${ }^{126}$ It declared independence on behalf of the colonies in a united manner. ${ }^{127}$ It requested that state legislatures take measures such as imposing embargoes on the export of needed commodities. ${ }^{128}$ It not only raised an army but also enacted the Articles of War to govern the army. ${ }^{129}$ It entered into diplomatic relations with foreign nations and attempted to negotiate peace. ${ }^{130} \mathrm{It}$ borrowed money and issued bills of credit. ${ }^{131}$ In short, it did many of the functions of a government formed under a proper constitution.

Although the Articles of Confederation were not perfect, they were sufficient to allow Congress to achieve many admirable accomplishments. Under the Articles of Confederation, Congress led a successful war effort under extremely difficult circumstances. The Articles kept the thirteen colonies together in times of great stress even though they often had very differing interests. The Articles allowed Congress to make foreign allies who provided loans and military assistance. ${ }^{132}$ The Articles also established a nation that secured recognition and a very favorable settlement from the United Kingdom in the Treaty of Paris in 1783.133 And in the Northwest Ordinance passed under the Articles of Confederation, Congress came up with a plan to organize the disputed western lands, to provide for the even-

12512 John Fiske, The Historical Writings of John Fiske 430-32 (1902).

126 See supra notes 41-44 and accompanying text.

127 See The Declaration of IndePendence pmbl. (U.S. 1776).

128 See, e.g., 11 Journals of the Continental Congress 1774-1789, supra note 112, at 569 (resolution recommending to the several states that they embargo wheat, rice, rye, Indian corn, flour, bread, beef, pork, and other commodities).

1295 Journals of the Continental Congress 1774-1789, supra note 41, at 788-807.

130 See id. at 490.

131 See id. at 551.

132 Articles of Confederation of 1781, art. VI.

133 See generally 1 Howard W. Preston, Documents Illustrative of American HisTORY 1606-1863 (1886). 
tual admission of new states into the Union, and to address some of the divisive issues presented by slavery. ${ }^{134}$

Yet, despite these successes, Congress struggled constantly with the inherent weakness and other flaws of the Confederation. Perhaps the best source for understanding the problems of the Articles of Confederation as they were perceived in the late 1780s is the Federalist Papers, a collection of eighty-seven essays written by Alexander Hamilton, James Madison, and John Jay in 1787 and 1788 to convince the people of New York to support ratification of the U.S. Constitution. ${ }^{135}$ Federalists Nos. 15 to 22 specifically addressed perceived "insufficiencies" and "other defects" in the Articles of Confederation. ${ }^{136}$

Finances were a great issue. Fighting a war and recovering from its aftermath cost a fortune. ${ }^{137}$ Scarcely a page of the Journals does not include discussion of the need to approve some great expense. ${ }^{138}$ As noted above, the states did not meet their obligations to provide for the common treasury. ${ }^{139}$ While Congress could make promises to pay in the future with bills of credit, these soon lost their currency as it appeared that Congress could never pay off its war debts. ${ }^{140}$ Federalist No. 15 captured the problem: "Do we owe debts to foreigners and to our own citizens contracted in a time of imminent peril for the preservation of our political existence? These remain without any proper or satisfactory provision for their discharge." 141

Foreign policy was also a difficulty. Although the Articles of Confederation in theory left diplomatic matters to Congress, the states engaged in their own international negotiations. They also refused to adhere to the terms of treaties. Federalist No. 22 lamented:

No nation acquainted with the nature of our political association would be unwise enough to enter into stipulations with the United States, conceding on their part privileges of importance, while they were apprised that the engagements on

134 See generally 1 Laurel Wendt, Illinois Legal Research Guide (2d ed. 2006).

135 See generally The Federalist Nos. 15-17, 21-22 (Alexander Hamilton), Nos. 18-20 (Alexander Hamilton and James Madison). For the purposes of this Article, the Federalist Papers are those edited by Clinton Rossiter.

136 The Federalist Nos. 15-17, 21-22 (Alexander Hamilton), Nos. 18-20 (Alexander Hamilton and James Madison) (Clinton Rossiter ed., 1961). The quoted words appear in the titles of these essays.

13715 Journals of the Continental Congress, supra note 63, at 1053.

138 See generally 1 Journals of the Continental Congress 1774-1789, supra note 25.

139 Supra notes 74-76 and accompanying text.

140 See 15 Journals of the Continental Congress 1774-1789, supra note 63, at $1053-54$.

141 The Federalist No. 15, at 101 (Alexander Hamilton) (Clinton Rossiter ed., 1961). 
the part of the Union might at any moment be violated by its members . . . . ${ }^{142}$

Militarily, despite the victory over the United Kingdom, the United States soon became weak. Though short-lived, Shay's Rebellion showed how emboldened disaffected citizens were and how weakly the United States military could respond. ${ }^{143}$ Federalist No. 19 said: "The small body of national troops, which has been judged necessary in time of peace, is defectively kept up, badly paid, infected with local prejudices, and supported by irregular and disproportionate contributions to the treasury." 144 Even worse, the gains of the War were being lost. The states were not complying with the Treaty of Paris, which required them to repay pre-Revolutionary War debts. This failure, in the view of the United Kingdom, justified keeping British forts in the Great Lakes region despite contrary provisions in the treaty. "Have we valuable territories and important posts in the possession of a foreign power which, by express stipulations, ought long since to have been surrendered?" asked Federalist No. 15. ${ }^{145}$

Another key problem was that Congress had very little legislative, executive, and judicial power. It had little authority to pass laws and almost no authority to enforce them. Federalist No. 16 remarked: "[I]f any State should be disaffected to the authority of the Union it could at any time obstruct the execution of its laws ..."; the national government must "stand in need of no intermediate legislations; but must itself be empowered to employ the arm of the ordinary magistrate to execute its own resolutions." 146 This essay later repeated the same theme:

The next most palpable defect of the existing Confederation is the total want of a SANCTION to its laws. The United States, as now composed, have no power to exact obedience, or punish disobedience to their resolutions, either by pecuniary mulcts, by a suspension or divestiture of privileges, or by any other constitutional means. ${ }^{147}$

Under the Articles of Confederation, the economy also suffered from state hindrances of commerce. Federalist No. 42 made an affirm-

142 The Federalist No. 22, at 139-40 (Alexander Hamilton) (Clinton Rossiter ed., 1961).

143 Rahul Tilva, Shays' Rebellion, Mount Vernon Ladies' Assoc., http:// www.mountvernon.org/digital-encyclopedia/article/shays-rebellion/ (last visited Dec. 26, 2016).

144 The Federalist No. 19, at 127 (Alexander Hamilton and James Madison) (Clinton Rossiter ed., 1961).

145 The Federalist No. 15, supra note 141, at 101 (Alexander Hamilton).

146 The Federalist No. 16, at 111-12 (Alexander Hamilton) (Clinton Rossiter ed., 1961).

147 The Federalist No. 21, at 134 (Alexander Hamilton) (Clinton Rossiter ed., 1961). 
ative case for giving Congress the power to regulate interstate commerce. It decried the "defect of power in the existing Confederacy to regulate the commerce between its several members" and emphasized the need for "the relief of the States which import and export through other States from the improper contributions levied on them by the latter." 148

\section{G. Replacement by the Constitution}

Perhaps the greatest achievement of Congress under the Articles of Confederation was its recognition that problems existed and its willingness to promote and accept reform. On February 21, 1787, Congress approved the calling of a convention to discuss and propose amendments to the Articles of Confederation. ${ }^{149}$ The Convention quickly got away from this initial goal. Instead of just drafting amendments to the Articles of Confederation, the assembly proposed a new Constitution. ${ }^{150}$ The Convention decided that the Constitution would go into effect if conventions in nine states ratified it. ${ }^{151}$ In this way, they bypassed the Confederation Congress and did not allow the state legislatures to vote on the Constitution.

The Convention also sidestepped the requirement that any amendments to the Articles of Confederation had to be approved by all of the states. ${ }^{152}$ While this step has provoked considerable academic discussion, it was largely overlooked as a serious issue. James Madison dismissed any concern in Federalist No. 40, saying this about critics who might insist on a unanimous ratification: "Let them declare, whether it was of most importance to the happiness of the people of America, that the Articles of Confederation should be disregarded, and an adequate government be provided, and the Union preserved; or that an adequate government should be omitted, and the Articles of Confederation preserved." 153 Madison and the other Framers must have remembered the delay and hardship caused by requiring all of the states to ratify the Articles of Confederation.

In the fall of 1787 and spring of 1788, the states held ratification conventions. ${ }^{154}$ One by one, states began approving the new Constitution. New Hampshire was the ninth state, followed closely by New

\footnotetext{
148 The Federalist No. 42, at 267 (James Madison) (Clinton Rossiter ed., 1961).

14932 Journals of the Continental Congress 1774-1789, supra note 44, at 71-74.

150 See id.

15134 Journals of the Continental Congress 1774-1789, supra note 34, at VII.

152 See Articles of Confederation of 1781, art. XIII.

153 The Federalist No. 40, at 249 (James Madison) (Clinton Rossiter ed., 1961).

154 See Kesavan, supra note 48, at 36.
} 
York and Virginia. ${ }^{155}$ In July 1788, although North Carolina and Rhode Island had not yet ratified, Congress acknowledged that a sufficient number of states had approved the Constitution. ${ }^{156}$ Congress then created a committee to report an "Act to Congress for putting the said constitution into operation." 157 On September 13, 1788, the Congress voted to implement the new Constitution, to establish New York as the capital, and to set March 4, 1789, as the day that the new government would start and the Confederation would end..$^{158}$

\section{Definitions of Original Meaning}

Judges, scholars, lawyers, and others often seek to discover the original meaning of the Constitution. This task is not always straightforward. The Constitution is now over 225 years old. During this time, some words have changed their meaning, background principles that once may have been generally known have now become obscure, and the intents and purposes of those who drafted the document may have been forgotten.

In addition, an important complication is that there is more than one definition of the term "original meaning." The term might refer to (1) the original intent of the Framers who drafted the Constitution at the Constitutional Convention; (2) the original understanding of the participants in the state ratification debates as to what they were approving; or (3) the original, objective (or public meaning) of the words and phrases in the Constitution without reference to any individual's or group's subjective intent or understanding. Other works have explored these different definitions at length, providing examples of how they might differ, identifying important figures who have favored one type of meaning over another, and so forth. ${ }^{159}$ This Article takes no position on the merits of one definition over another or whether one type of meaning should carry more weight in constitutional interpretation. Instead, the emphasis here is on clarity: distinguishing the different types of original meaning which the Articles of Confederation might help to establish.

When writers compare the text of the Constitution to the text of the Articles of Confederation, they are usually making arguments

155 Id. at 36 n.9.

15634 Journals of the Continental Congress 1774-1789, supra note 34, at 304.

157 Id. at 281.

158 Id. at 515.

159 See, e.g., Gregory E. Maggs, Which Original Meaning of the Constitution Matters to Justice Thomas?, 4 N.Y.U. J.L. \& LiBerTy 494, 495 (2009). 
about the original, objective meaning of the Constitution. ${ }^{160}$ The same is usually true when they compare the structure of the government set up by the Constitution to the structure of the government set up by the Articles of Confederation. ${ }^{161}$ This type of original meaning is objective because it looks for reasonable inferences that might be drawn from the comparison, rather than what Madison, Hamilton, or anyone else subjectively intended the Constitution to mean or understood the Constitution to mean. ${ }^{162}$

In contrast, when writers make arguments about how the Constitution was designed to address perceived problems with the Articles of Confederation, they more typically are addressing the original intent or the original understanding. ${ }^{163}$ The inquiry is not objective because it requires consideration of extrinsic facts about the Articles' perceived defects and the intended improvements found in the Constitution. As explained more fully below, these arguments do rely on the Articles of Confederation, but they also might rely on other sources, such as remarks at the Constitutional Convention, statements in the Federalist Papers, and so forth. The goal in discerning the original intent or original understanding is to get at what the Framers or ratifiers subjectively thought they were accomplishing. ${ }^{164}$

More details relating to these matters appear in the Part that follows. ${ }^{165}$ What is most important going forward is only that the readers recognize that more than one possible "original" meaning may exist ${ }^{166}$ and to think critically about how different kinds of arguments might be addressing different kinds of original meaning. ${ }^{167}$

160 See infra Section III.A.

161 See infra Section III.B.

162 See Maggs, A Concise Guide to Using Dictionaries from the Founding Era, supra note 11, at 363-64 (describing differences between subjective original meaning and objective original meaning).

163 See infra Section III.A.

164 See Maggs, A Concise Guide to Using Dictionaries from the Founding Era, supra note 11, at 362-63 (describing original intent as an inquiry into the subjective goals of the Framers). 165 See infra Part III.

166 See Maggs, A Concise Guide to Using Dictionaries from the Founding Era, supra note 11, at 362 (describing three different types of original meaning); see infra ConcLusion.

167 Compare infra Section III.A (discussing claims about original meaning based on comparing the text of the Constitution and Articles of Confederation), and Section III.B (discussing claims about original meaning based on comparing the governmental structure established by the Constitution and the Articles of Confederation), with Section III.C (discussing claims about original meaning based on extrinsic evidence relating to the goals of the Framers when replacing the Articles of Confederation with the Constitution), and Section III.D (discussing claims about original meaning based on the theory that the Articles of Confederation supplement, rather than replace, the Constitution). 
III. Four Ways of Using the Articles of Confederation to Make Claims About the Original Meaning of the Constitution

Claims about the original meaning of the Constitution that rely on the Articles of Confederation tend to fall into four categories. The following discussion identifies these categories, provides multiple illustrations from Supreme Court decisions, and then considers some of the rhetorical strengths and weaknesses of each type of claim.

\section{A. Claims Based on a Comparison of the Text of the Constitution to the Text Used in the Articles of Confederation}

Many claims about the original meaning of the Constitution rely on a comparison of the text of the Constitution to the text of the Articles of Confederation. If the texts are exactly the same or nearly identical, this may suggest that the Constitution simply continued the work of the Articles of Confederation. For example, as the Supreme Court observed in Baker v. General Motors Corp., ${ }^{168}$ the first sentence of the Full Faith and Credit Clause is almost the same as an antecedent provision in the Articles of Confederation. ${ }^{169}$ The Constitution says: "Full Faith and Credit shall be given in each State to the public Acts, Records, and judicial Proceedings of every other State." 170 Using very similar language, the Articles of Confederation formerly said: "Full faith and credit shall be given in each of these states to the records, acts and judicial proceedings of the courts and magistrates of every other state." ${ }^{171}$ The evident conclusion is that the Constitution did not change the law on this point; as the Supreme Court put it, the two provisions are of "the same order." 172

This line of reasoning is not very controversial, but it is also not necessarily very helpful. Knowing that a provision in the Constitution has the same meaning as an antecedent provision in the Articles of Confederation does not facilitate interpretation of the constitutional provision absent evidence of what the earlier provision meant. Such evidence about the meaning of the Articles of Confederation simply may be scarce. Still, some researchers have managed to find useful information in historical records. For example, Professor David Engdahl has uncovered cases from the 1780s interpreting the Full Faith

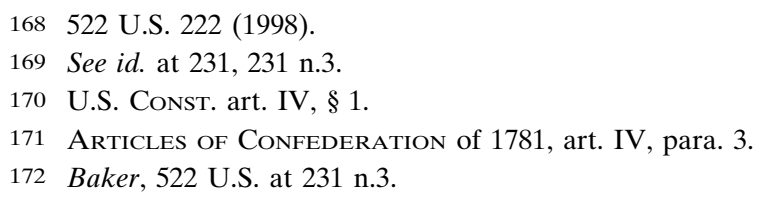


and Credit Clause in the Articles of Confederation that yield clues about the meaning of the corresponding clause in the Constitution. ${ }^{173}$ This approach may prove fruitful with respect to other provisions if similar evidence can be discovered.

When the text of the Constitution differs from an antecedent provision in the Articles of Confederation, sometimes the change indicates something about the meaning of the Constitution. As described in some detail above, ${ }^{174}$ a famous example appears in McCulloch $v$. Maryland. ${ }^{175}$ Chief Justice Marshall in that case concluded that Congress has implied legislative powers based in part on a comparison of the Tenth Amendment to Article II of the Articles of Confederation. ${ }^{176} \mathrm{He}$ observed that the Tenth Amendment limits Congress to those powers "delegated by the Constitution," 177 while Article II restricted the Confederation Congress to the powers "expressly delegated." ${ }^{178}$ Chief Justice Marshall reasoned that omission of the word "expressly" from the Tenth Amendment indicated that the Framers intended the Constitution to give implied power to Congress. ${ }^{179}$

But a difference in language does not necessarily imply that the Constitution has a different meaning from the Articles of Confederation. Instead, the variation in wording might simply reflect an alternative manner of drafting. As mentioned previously, ${ }^{180}$ the Constitution addresses more subjects than the Articles of Confederation, but in general tends to treat them in a less verbose manner. One example concerns the Privileges and Immunities of citizens. The Constitution simply says: "The Citizens of each State shall be entitled to all Privileges and Immunities of Citizens in the several States." 181 The antecedent of this clause appears in Article IV of the Articles of Confederation, ${ }^{182}$ and it is much longer and more detailed:

The better to secure and perpetuate mutual friendship and intercourse among the people of the different states in this union, the free inhabitants of each of these states, paupers, vagabonds and fugitives from Justice excepted, shall be enti-

173 See David E. Engdahl, The Classic Rule of Faith and Credit, 118 YAle L.J. 1584, 1614-19 (2009).

174 See supra notes 2-6 and accompanying text.

17517 U.S. (4 Wheat.) 316 (1819).

176 See id. at 384 (citing U.S. Const. amend. X)

177 See id. at 406 (citing Articles of Confederation of 1781, art. II).

178 Id.

179 Id. at $406-07$.

180 See supra Section I.C.

181 U.S. Const. art. IV, § 2, cl. 1.

182 Articles of Confederation of 1781 , art. IV. 
tled to all privileges and immunities of free citizens in the several states; and the people of each state shall have free ingress and regress to and from any other state, and shall enjoy therein all the privileges of trade and commerce, subject to the same duties, impositions and restrictions as the inhabitants thereof respectively, provided that such restrictions shall not extend so far as to prevent the removal of property imported into any state, to any other State of which the Owner is an inhabitant; provided also that no imposition, duties or restriction shall be laid by any state, on the property of the united states, or either of them. ${ }^{183}$

Comparing these two clauses reveals a number of omissions. For instance, the Privileges and Immunities Clause does not expressly mention a right to "free ingress and regress to and from any other state," as did the Articles of Confederation. Does this omission mean that the drafters intended to eliminate the right to travel across state lines as one of the privileges protected by the Clause? In Zobel v. Williams, ${ }^{184}$ the Supreme Court concluded that it did not, explaining:

While the Framers of our Constitution omitted the reference to "free ingress and regress," they retained the general guaranty of "privileges and immunities." Charles Pinckney, who drafted the current version of Art. IV, told the Convention that this Article was "formed exactly upon the principles of the 4th article of the present Confederation." Commentators, therefore, have assumed that the Framers omitted the express guaranty merely because it was redundant, not because they wished to excise the right from the Constitution. ${ }^{185}$

These two examples from McCulloch v. Maryland and Zobel v. Williams reveal a simply stated difficulty: a divergence between the text of the Constitution and the text of the Articles of Confederation sometimes indicates a difference in meaning and sometimes does not. Unfortunately, no simple formula exists for telling the two situations apart. As a result, in each instance of a difference in wording, researchers must examine the evidence in a lawyerly manner, draw a logical conclusion about what it shows, and then explain the reasoning in much the same way that the Supreme Court did in these two cases.

In some instances, a provision in the Constitution has no clear antecedent in the Articles of Confederation. In this situation, courts

183 Id. art. IV, para. 1.

184457 U.S. 55 (1982).

185 Id. at $79-80$ (citation omitted). 
generally conclude that the constitutional provision creates a new power or new limitation that did not exist under the Articles of Confederation. For example, in Central Virginia Community College v. $K a t z, 186$ the Supreme Court observed that while the Constitution contains a clause empowering Congress to pass uniform laws on the subject of bankruptcy, no such clause existed under the Articles of Confederation. ${ }^{187}$ The Court concluded that the constitutional clause must have conferred a power to address problems that had arisen in cases before the Constitution's ratification. ${ }^{188}$

In other instances, the situation is reversed: A provision in the Articles of Confederation has no analogue in the Constitution. For example, a clause in Article IX of the Articles of Confederation, expressly gave Congress the power to regulate Indian affairs, saying:

The united states, in congress assembled, shall also have the sole and exclusive right and power of ... regulating the trade and managing all affairs with the Indians, not members of any of the states; provided that the legislative right of any state, within its own limits, be not infringed or violated . . . . ${ }^{189}$

In contrast, although the Constitution empowers Congress to regulate "commerce ... among ... the Indian Tribes," 190 the Constitution contains no provision allowing Congress to regulate Indian "affairs" more generally. In his concurring opinion in Adoptive Couple v. Baby Girl, ${ }^{191}$ Justice Thomas observed that at the Constitutional Convention, James Madison had proposed giving Congress the power to regulate "Indian affairs" but the Convention did not adopt this proposal. ${ }^{192}$ He accordingly concluded:

It is, thus, clear that the Framers of the Constitution were alert to the difference between the power to regulate trade with the Indians and the power to regulate all Indian affairs. By limiting Congress' power to the former, the Framers declined to grant Congress the same broad powers over Indian affairs conferred by the Articles of Confederation. ${ }^{193}$

\footnotetext{
186546 U.S. 356 (2006).

187 Id. at 368.

188 See id. at 369.

189 Articles of Confederation of 1781, art. IX, para. 4 (emphasis added).

190 U.S. Const. art. I, § 8, cl. 3.

191133 S. Ct. 2552 (2013).

192 See id. at 2569 (Thomas, J., concurring).

193 Id. (citing Saikrishna Prakash, Against Tribal Fungibility, 89 Cornell L. Rev. 1069, 1090 (2004)).
} 
As the foregoing discussion suggests, efforts to compare the text of the Constitution to the text of the Articles of Confederation generally seek to establish the original, objective meaning of the Constitution. They rely on logical inferences from the language used in each document more than on extrinsic evidence about the intentions of the Framers or the understanding of the participants at the state ratifying convention. Accordingly, they may complement other sources of evidence about the original, objective meaning, such as dictionaries from the Founding Era. ${ }^{194}$

\section{B. Claims Based on a Comparison of the Structure of Government Set Up by the Constitution to the Structure of the Government Established by the Articles of Confederation}

Structural constitutional arguments seek to determine the answers to specific constitutional questions by looking at the organization of the government set up by the Constitution. A well-known example appears in Marbury v. Madison. ${ }^{195}$ Chief Justice Marshall observed that the Constitution creates a legislature with defined and limited powers. ${ }^{196} \mathrm{He}$ then asked rhetorically, "[t]o what purpose are powers limited, and to what purpose is that limitation committed to writing, if these limits may, at any time, be passed by those intended to be restrained?" ${ }^{197} \mathrm{He}$ reasoned that the limited powers would not make sense if Congress could transcend the limits without consequence. ${ }^{198}$ This structural reasoning supported Chief Justice Marshall's conclusion that the acts of Congress that are "repugnant to the constitution" cannot become law. ${ }^{199}$

The Articles of Confederation may contribute to structural constitutional arguments. Sometimes comparing the structure of the government under the Constitution to the structure of the government under the Articles of Confederation helps with reasoning about par-

194 The original, objective meaning may be consistent with original intent of the Framers and the original understanding of the ratifiers, and sometimes the courts look at more than one type of meaning. For example, in Adoptive Couple v. Baby Girl, Justice Thomas bolstered his conclusions about Congress's power with respect to Indian affairs by looking at James Madison's proposed amendment at the Constitutional Convention. $133 \mathrm{~S}$. Ct. at 2569. And based on inferences drawn from the text in McCulloch v. Maryland, Chief Justice Marshall drew an inference about what "the men who drew and adopted" the Tenth Amendment "probably" intended to accomplish. McCulloch v. Maryland, 17 U.S. (4 Wheat.) 316, 406-07 (1819).

1955 U.S. (1 Cranch) 137, 176 (1803).

196 See id. at 176.

197 Id.

198 See id. at 176-77.

199 Id. at 177. 
ticular issues. Two examples of this kind of claim about the original meaning appear in Justice Stevens's separate opinions in New York $v$. United States ${ }^{200}$ and Printz v. United States. ${ }^{201}$ Both cases concerned intergovernmental immunity. In New York v. United States, the Court held that the federal government could not require a state to take legislative action. ${ }^{202}$ In Printz, the Court held that the federal government could not require state officials to implement federal legislation. ${ }^{203}$ Justice Stevens disagreed with these conclusions. In New York v. United States, Justice Stevens advanced this structural argument:

Under the Articles of Confederation, the Federal Government had the power to issue commands to the States. Because that indirect exercise of federal power proved ineffective, the Framers of the Constitution empowered the Federal Government to exercise legislative authority directly over individuals within the States, even though that direct authority constituted a greater intrusion on state sovereignty. Nothing in that history suggests that the Federal Government may not also impose its will upon the several States as it did under the Articles. The Constitution enhanced, rather than diminished, the power of the Federal Government. ${ }^{204}$

In other words, a comparison of the structure of the government under the Articles of Confederation to the government under the Constitution showed that a change had occurred but that the change did not take away a power that formerly had belonged to the government. ${ }^{205}$ Justice Stevens used similar reasoning in Printz:

Under the Articles of Confederation the National Government had the power to issue commands to the several sovereign States, but it had no authority to govern individuals directly. Thus, it raised an army and financed its operations by issuing requisitions to the constituent members of the Confederacy, rather than by creating federal agencies to draft soldiers or to impose taxes. That method of governing proved to be unacceptable, not because it demeaned the sovereign character of the several States, but rather because it was cumbersome and inefficient. ${ }^{206}$

200505 U.S. 144, 210 (1992) (Stevens, J., concurring in part and dissenting in part).

201521 U.S. 898, 939 (1997) (Stevens, J., dissenting).

202 New York v. United States, 505 U.S. at 178-79.

203 Printz, 521 U.S. at 936.

204 New York v. United States, 505 U.S. at 210 (Stevens, J., concurring in part and dissenting in part) (citation omitted).

205 See id.

206 Printz, 521 U.S. at 945 (Stevens, J., dissenting). 
Again, Justice Stevens was making a structural constitutional argument, using the Articles of Confederation to help determine the structure of the Constitution, which in turn he used to address the specific issue before the Court.

Attempting to determine the original meaning of the Constitution by comparing the structure of the government under the Constitution to the structure of the government under the Articles of Confederation is sometimes difficult because the relevant history may not be clear. An example of this problem appears in Seminole Tribe of Florida v. Florida. ${ }^{207}$ In that case, the Seminole tribe sued the State of Florida in federal court, claiming that Florida had not complied with its obligations under a federal statute regulating gambling. ${ }^{208}$ The Supreme Court had to determine whether the Indian Commerce Clause gave Congress power to abrogate the state's Eleventh Amendment immunity. ${ }^{209}$ The Solicitor General's brief in the case advanced a structural argument about state sovereignty that relied in part on a comparison of the Constitution to the Articles of Confederation. ${ }^{210}$ But the Court eschewed this approach in deciding the case, presumably because of its difficulty. The Court chose not to "calculate exactly how close the American States came to sovereignty in the classic sense prior to ratification of the Constitution," 211 and ruled on other grounds.

Comparing constitutional structures is often more complicated than comparing the texts. In New York v. United States, Justice Stevens appears to have been relying on the common logical inference that "the greater includes the lesser." Because Congress generally has more power under the Constitution than it had under the Articles of Confederation, he concluded that it must have whatever powers the Confederation Congress had. ${ }^{212}$ This reasoning may hold true in some instances, but it is subject to counter examples. As Justice Thomas's opinion in Seminole Tribe indicates, the Confederation Congress may have had some powers-like regulating Indian affairs-that Congress currently does not have. Put simply, while the Constitution generally expanded Congress's powers, it also contracted a few of them. The

207517 U.S. 44 (1996).

208 See id. at 51-52.

209 See id. at 47.

210 See Brief for the United States as Amicus Curiae Supporting Petitioner at 22-24, Seminole Tribe of Fla. v. Florida, 517 U.S. 44 (1995) (No. 94-12).

211 Seminole Tribe of Fla., 517 U.S. at 150.

212 See New York v. United States, 505 U.S. 144, 210 (1992) (Stevens, J., dissenting). 
greater powers Congress now enjoys, therefore, do not always include the lesser powers that the Confederation Congress previously had.

Structural comparisons, like textual comparisons, generally support claims about the original, objective meaning of the Constitution. They do not focus on the subjective intentions of the Framers or understandings of those who ratified the Constitution, but instead on logical reasoning.

\section{Claims Based on Extrinsic Evidence of the Framers' Goals in Replacing the Articles of Confederation with the Constitution}

In some instances, in attempting to discern the original meaning of the Constitution, the Supreme Court has focused not just on the text and structure of the Articles of Confederation, but also on criticism of the Articles of Confederation during the Founding period. ${ }^{213}$ The Supreme Court has reasoned that the Framers of the Constitution intended to correct these deficiencies and that those who ratified the Constitution understood that it would accomplish this goal. ${ }^{214}$ Most frequently, the Court has relied on the Federalist Papers to discern the Framers' concerns about the Articles of Confederation, although other sources also might serve this function equally well. ${ }^{215}$

The clearest cases of this type of reasoning about the original meaning of the Constitution concern the Commerce Clause, which empowers Congress to "regulate Commerce . . . among the several States." 216 This provision has no antecedent in the Articles of Confederation, and the lack of national power over commerce was seen as a major problem in the 1780 s. ${ }^{217}$ In Federalist No. 42, James Madison identified the inability of Congress to regulate interstate commerce as a "defect of power in the existing Confederacy" which has "been clearly pointed out by experience." ${ }^{218} \mathrm{He}$ then explained that a "very material object" of granting power to Congress to regulate interstate commerce was to allow Congress to provide for "the relief of the States which import and export through other States from the improper contributions levied on them by the latter." 219

The Supreme Court has interpreted the Commerce Clause in light of this criticism of the Articles of Confederation. For example, in

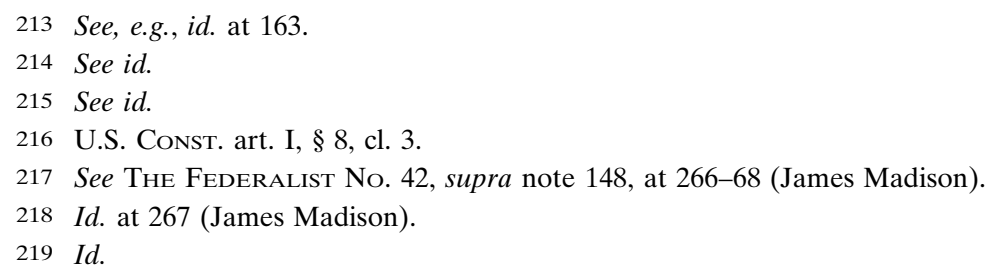


Dennis v. Higgins, ${ }^{220}$ the Supreme Court cited Federalist Nos. 7, 11, 22,42 , and 53, which all described the poor economic conditions that prevailed prior to adoption of the Constitution. ${ }^{221}$ The Court explained: "The lack of a national power over commerce during the Articles of Confederation led to ongoing disputes among the States, and the prospect of a descent toward even more intense commercial animosity was one of the principal arguments in favor of the Constitution."222 Other cases have cited the same experience under the Articles of Confederation when interpreting the Commerce Clause. ${ }^{223}$

Claims that rely on criticisms of the Articles of Confederation typically seek to establish what the Framers subjectively intended or the participants at the state ratifying conventions subjectively understood the Constitution to accomplish. Unlike claims based on a comparison of texts or governmental structures, they necessarily rely on extrinsic evidence that typically would not affect the original, objective meaning of the text of the Constitution. In particular cases, however, all three types of meaning might be consistent.

Researchers making claims about the original meaning of a constitutional provision that rely on this kind of reasoning must undertake several steps. First, they must find some criticism of the Articles of Confederation-in the Federalist Papers or elsewhere-that is addressed to the same issue as the constitutional provision. Then, researchers must show in some way that the persons who framed and ratified the Constitution were familiar with the criticism. For instance, perhaps they remarked on it at the Constitutional Convention or in one of the state ratifying conventions. Finally, researchers must find indications that the Constitution was designed or understood to address and remedy the criticism of the Articles of Confederation. A deficiency in any link in this chain would weaken the claim about the original meaning.

\section{Claims Based on the Controversial Theory that the Constitution}

Did Not Fully Replace the Articles and that the Articles

Therefore Continue to Supplement the Constitution

A fourth type of claim about the meaning of the Constitution rests on a theory that the Constitution implicitly continues some of the

220498 U.S. 439 (1991).

221 Id. at 453-54 (Kennedy, J., dissenting).

222 Id. at 453 (Kennedy, J., dissenting).

223 See, e.g., EEOC v. Wyoming, 460 U.S. 226, 244-45, 245 n.1 (1983) (Stevens, J., concurring). 
principles established by the Articles of Confederation. The theory is controversial because it goes against the generally accepted idea that the Constitution replaced the Articles of Confederation, and that the Articles, like a repealed statute or rescinded treaty, have no continuing validity. Yet, despite being somewhat counterintuitive, the theory has a strong pedigree and appears to be correct at least in some instances.

A very simple illustration of the theory, with little practical consequence, concerns the name "United States of America." When and how did this become the official title of our national government? The answer appears in the first article of the Articles of Confederation, which announced: "The Stile of this confederacy shall be, 'The United States of America.'”224 The Constitution contains no comparable provision expressly conferring a name on the new Republic. Instead, the Constitution's preamble and several subsequent provisions simply use the name "United States of America," or "United States,"225 apparently assuming that the name given to the national government under the Articles of Confederation would remain in effect-which history shows it did.

A more significant example concerns Article XIII of the Articles of Confederation, which declares that "the union shall be perpetual." 226 Nothing in the Constitution addresses this issue, a point that became evident before and during the Civil War when some states claimed the power to secede. In his first Inaugural Address, Lincoln believed secession was not possible. Drawing on the Articles of Confederation, Lincoln said:

[W]e find the proposition that, in legal contemplation, the Union is perpetual, confirmed by the history of the Union itself. The Union is much older than the Constitution. It was formed in fact, by the Articles of Association in 1774. It was matured and continued by the Declaration of Independence in 1776. It was further matured and the faith of all the then thirteen States expressly plighted and engaged that it should be perpetual, by the Articles of Confederation in 1778. And finally, in 1787, one of the declared objects for ordaining and establishing the Constitution, was "to form a more perfect union."227

224 Articles of Confederation of 1781, art. I.

225 U.S. CONST. pmbl.

226 Articles of Confederation of 1781, art. XIII.

227 Abraham Lincoln, First Inaugural Address-Final Text (Mar. 4, 1861), in 4 THE CoL Lected Works of Abraham Lincoln 262, 265 (Roy P. Basler ed., 1953) (footnote omitted). 
In this passage, President Lincoln assumes that the Constitution continued the principle of perpetual union formally established by Article XIII of the Articles of Confederation.

This question of whether the Constitution allows states to secede ultimately came before the Supreme Court in 1868, in Texas $v$. White. 228 That case concerned U.S. government bonds worth $\$ 5$ million that were issued to the state government of Texas in settlement of certain boundary claims. ${ }^{229}$ After the Civil War, litigation arose about whether the bonds could be enforced. ${ }^{230}$ After describing how the "insurgent legislature" voted to secede from the United States, ${ }^{231}$ the Supreme Court considered two fundamental issues: "Did Texas, in consequence of these acts, cease to be a State? Or, if not, did the State cease to be a member of the Union?" 232 The Court ultimately held that the acts of secession were null and void. ${ }^{233}$ Echoing what President Lincoln had said, the Court ruled:

[The Union of the States] received definite form, and character, and sanction from the Articles of Confederation. By these the Union was solemnly declared to "be perpetual." And when these Articles were found to be inadequate to the exigencies of the country, the Constitution was ordained "to form a more perfect Union." It is difficult to convey the idea of indissoluble unity more clearly than by these words. What can be indissoluble if a perpetual Union, made more perfect, is not?234

A third example of this type of claim about the original meaning of the Constitution concerns the obligation of the states jointly to respond to external threats. Article III of the Articles of Confederation established a duty of mutual self-defense, proclaiming:

The said states hereby severally enter into a firm league of friendship with each other, for their common defence, . . . binding themselves to assist each other, against all force offered to, or attacks made upon them, or any of them, on account of religion, sovereignty, trade, or any other pretence whatever. ${ }^{235}$

22874 U.S. (7 Wall.) 700 (1868), overruled in part by Morgan v. United States, 113 U.S. 476 (1885).

229 See White, 74 U.S. at 703.

230 See id. at 717.

231 Id. at 718.

232 Id. at 724.

233 See id. at 726.

234 Id. at 725.

235 Articles of Confederation of 1781, art. III. 
The Constitution mentions in the preamble that a goal of the Constitution is to "provide ... for the common defence" 236 and that Congress can spend money for the "common defense," but the Constitution does not say expressly that all states will respond to an attack against anyone of them. Still, the obligation of mutual self-defense may continue. 237

Although established by history, this line of argumentation raises a few difficult theoretical questions. One issue is how the Articles of Confederation might bind the thirty-seven out of fifty states that never ratified them. Perhaps the Constitution implicitly incorporates some prior principles from the Articles and all states became bound by them when they ratified the Constitution. A second question is why the Framers of the Constitution would have wanted to preserve important principles from the Articles of Confederation but did not address them with explicit provision. Perhaps they thought they were so self-evident that they required no discussion. Unfortunately, neither President Lincoln, nor the Supreme Court, has provided clear answers to these questions.

\section{CONCLUSION}

The Articles of Confederation joined the states in their first formal union over 230 years ago. Although the Articles remained in effect for only eight years, some good can come even from experiments that ultimately fail. Experience under the Articles of Confederation greatly influenced the drafting of the Constitution. As this Article has shown, the Articles of Confederation serve a very important continuing role by providing evidence, in various ways, of the original meaning of the Constitution. The Supreme Court has cited the Articles of Confederation in more than 180 cases. Reviewing these decisions reveals four general types of constitutional arguments that in some way rely on the Articles of Confederation. Although none of them is free from difficulty, each at least rests on a sound theoretical basis. Anyone making or evaluating claims about the original meaning of the Constitution should consider how the Articles of Confederation might provide additional or contrary evidence.

236 U.S. Const. pmbl.

237 Cf. Arver v. United States, 245 U.S. 366, 380 (1918) (upholding federal law drafting men for service in the Army in part on grounds that states provided men for the Continental Army under the Articles of Confederation). 


\section{Appendix A: Annotated Articles of Confederation}

Below is an annotated copy of the Articles of Confederation. The text of the Articles is in Roman type. ${ }^{238}$ The annotations are in italics and the text of the United States Constitution is underlined. Paragraph designators, which are indicated in brackets (e.g., "[1]") have been added for clarity; official versions of the Articles of Confederation do not include the paragraph designators. The annotations principally serve to link the clause in the Articles of Confederation to closely related clauses in the Constitution.

\section{ARTICLES OF CONFEDERATION OF 1781}

To all to whom these Presents shall come, we, the undersigned Delegates of the States affixed to our Names send greeting. Whereas the Delegates of the United States of America in Congress assembled did on the fifteenth day of November in the year of our Lord One Thousand Seven Hundred and Seventy seven, and in the Second Year of the Independence of America agree to certain articles of Confederation and perpetual Union between the States of Newhampshire, Massachusetts-bay, Rhodeisland and Providence Plantations, Connecticut, New York, New Jersey, Pennsylvania, Delaware, Maryland, Virginia, North Carolina, South Carolina, and Georgia in the Words following, viz. "Articles of Confederation and perpetual Union between the States of Newhampshire, Massachusetts-bay, Rhodeisland and Providence Plantations, Connecticut, New York, New Jersey, Pennsylvania, Delaware, Maryland, Virginia, North Carolina, South Carolina, and Georgia.

I. The Stile of this confederacy shall be, "The United States of America."

The Constitution contains no provision conferring a name on the Republic. The preamble, however, identifies the Constitution as being "for the United States of America." U.S. CONST. pmbl.

II. Each state retains its sovereignty, freedom and independence, and every Power, Jurisdiction and right, which is not by this confederation expressly delegated to the United States, in Congress assembled.

Although the Constitution presupposes some degree of state autonomy, it does not expressly guarantee (or even) address state "sover-

238 The text of the Articles of the Confederation is taken from the Our Documents initiative by the National History Day, The National Archives and Records Administration, and USA Freedom Corps. Transcript of Articles of Confederation (1777), Our Documents, http:// www.ourdocuments.gov/doc.php?doc=3\&page=transcript (last visited Dec. 20, 2016). 
eignty," "freedom," or "independence." But the Tenth Amendment says: "The powers not delegated to the United States by the Constitution, nor prohibited by it to the States, are reserved to the States respectively, or to the people." U.S. Const. amend. X.

III. The said states hereby severally enter into a firm league of friendship with each other, for their common defence, the security of their Liberties, and their mutual and general welfare,

This provision resembles the Constitution's preamble, which says: "We the People of the United States, in Order to form a more perfect Union, establish Justice, insure domestic Tranquility, provide for the common defence, promote the general Welfare, and secure the Blessings of Liberty to ourselves and our Posterity, do ordain and establish this Constitution for the United States of America." U.S. Const. pmbl.

binding themselves to assist each other, against all force offered to, or attacks made upon them, or any of them, on account of religion, sovereignty, trade, or any other pretence whatever.

The Constitution does not expressly commit the states to defend each other. But it does provide that "Congress shall have Power... To provide for calling forth the Militia to execute the Laws of the Union, suppress Insurrections and repel Invasions.” U.S. CONST. art. I, \& 8, cl. 15.

IV. [1] The better to secure and perpetuate mutual friendship and intercourse among the people of the different states in this union, the free inhabitants of each of these states, paupers, vagabonds and fugitives from Justice excepted, shall be entitled to all privileges and immunities of free citizens in the several states;

"The Citizens of each State shall be entitled to all Privileges and Immunities of Citizens in the several States." U.S. CoNst. art. IV, $\S 2$, cl. 1 .

and the people of each state shall have free ingress and regress to and from any other state,

Not expressly addressed in the text of the Constitution.

and shall enjoy therein all the privileges of trade and commerce, subject to the same duties, impositions and restrictions as the inhabitants thereof respectively,

Not expressly addressed in the text of the Constitution.

provided that such restrictions shall not extend so far as to prevent the removal of property imported into any state, to any other State of which the Owner is an inhabitant; 
Not expressly addressed in the text of the Constitution. This provision apparently served to allow a slaveowner, who had brought a slave into a free state, to take the slave back out of the state. Brainerd Currie \& Herma Hill Schreter, Unconstitutional Discrimination in the Conflict of Laws: Privileges and Immunities, 69 YALE L.J. 1323, 1336 n.35 (1960). This was a concern following Somerset v. Stewart, 98 Eng. Rep. 499 (1772), in which the King's Bench freed a slave brought from Virginia to England. The Constitution addressed fugitive slaves in Article IV, saying "No Person held to Service or Labour in one State, under the Laws thereof, escaping into another, shall, in Consequence of any Law or Regulation therein, be discharged from such Service or Labour. but shall be delivered up on Claim of the Party to whom such Service or Labour may be due." U.S. ConsT. art. IV, \& 2, cl. 3.

provided also that no imposition, duties or restriction shall be laid by any state, on the property of the united states, or either of them.

Not expressly addressed in the text of the Constitution. The Supreme Court, however, has held that the states do not have the power to tax the federal government in McCulloch v. Maryland, 17 U.S. (4 Wheat.) 316 (1819).

[2] If any Person guilty of, or charged with, treason, felony, or other high misdemeanor in any state, shall flee from Justice, and be found in any of the united states, he shall upon demand of the Governor or executive power of the state from which he fled, be delivered up, and removed to the state having jurisdiction of his offense.

"A Person charged in any State with Treason, Felony, or other Crime, who shall flee from Justice, and be found in another State, shall on Demand of the executive Authority of the State from which he fled, be delivered up, to be removed to the State having Jurisdiction of the Crime." U.S. Const. art. IV, \& 2, cl. 2.

[3] Full faith and credit shall be given in each of these states to the records, acts and judicial proceedings of the courts and magistrates of every other state.

"Full Faith and Credit shall be given in each State to the public Acts, Records, and judicial Proceedings of every other State. And the Congress may by general Laws prescribe the Manner in which such Acts, Records and Proceedings shall be proved, and the Effect thereof." U.S. CONST. art. IV, $\& 1$.

V. [1] For the more convenient management of the general interests of the united states, delegates shall be annually appointed in such manner as the legislature of each state shall direct, to meet in Congress on the first Monday in November, in every year, with a power 
reserved to each state to recall its delegates, or any of them, at any time within the year, and to send others in their stead, for the remainder of the Year.

The Constitution originally provided that the state legislatures would appoint senators from each state: "The Senate of the United States shall be composed of two Senators from each State, chosen by the Legislature thereof, for six Years...." U.S. Const. art. I, \& 3, cl. 1.

[2] No State shall be represented in Congress by less than two, nor by more than seven Members;

"Representatives... shall be apportioned among the several States which may be included within this Union, according to their respective Numbers, which shall be determined by adding to the whole Number of free Persons, including those bound to Service for a Term of Years, and excluding Indians not taxed, three fifths of all other Persons. The actual Enumeration shall be made within three Years after the first Meeting of the Congress of the United States, and within every subsequent Term of ten Years, in such Manner as they shall by Law direct. The Number of Representatives shall not exceed one for every thirty Thousand, but each State shall have at Least one Representative; and until such enumeration shall be made, the State of New Hampshire shall be entitled to chuse three, Massachusetts eight, Rhode Island and Providence Plantations one, Connecticut five, New York six, New Jersey four, Pennsylvania eight, Delaware one, Maryland six, Virginia ten, North Carolina five, South Carolina five, and Georgia three." U.S. CONST. art. I, $\$ 2$, cl. 3. "The Senate of the United States shall be composed of two Senators from each State, chosen by the Legislature thereof, for six Years; and each Senator shall have one Vote." U.S. Const. art. I, \&3, cl. 1 .

and no person shall be capable of being delegate for more than three years, in any term of six years;

No comparable provision in the text of the Constitution.

nor shall any person, being a delegate, be capable of holding any office under the united states, for which he, or another for his benefit receives any salary, fees or emolument of any kind.

"No Senator or Representative shall, during the Time for which he was elected, be appointed to any civil Office under the Authority of the United States, which shall have been created, or the Emoluments whereof shall have been encreased during such time; and no Person holding any Office under the United States, shall be a Member of either House during his Continuance in Office." U.S. Const. art. I, $\$$ 6, cl. 2. 
[3] Each State shall maintain its own delegates in a meeting of the states, and while they act as members of the committee of the states.

"The Senators and Representatives shall receive a Compensation for their Services, to be ascertained by Law, and paid out of the Treasury of the United States." U.S. ConsT. art. I, \& 6, cl. 1.

[4] In determining questions in the united states, in Congress assembled, each state shall have one vote.

"[E]ach Senator shall have one Vote." U.S. Const. art. I, § 3, cl. 1. Note: The Constitution does not expressly say that each representative will have one vote.

[5] Freedom of speech and debate in Congress shall not be impeached or questioned in any Court, or place out of Congress, and the members of congress shall be protected in their persons from arrests and imprisonments, during the time of their going to and from, and attendance on congress, except for treason, felony, or breach of the peace.

"They shall in all Cases, except Treason, Felony and Breach of the Peace, be privileged from Arrest during their Attendance at the Session of their respective Houses, and in going to and returning from the same; and for any Speech or Debate in either House, they shall not be questioned in any other Place." U.S. CoNST. art. I, \& 6, cl. 1.

VI. [1] No State, without the Consent of the united States, in congress assembled, shall send any embassy to, or receive any embassy from, or enter into any conference, agreement, alliance, or treaty with any King, prince or state;

"No State shall enter into any Treaty, Alliance, or Confederation ...." U.S. Const. art. I, \& 10, cl. 1. "No State shall, without the Consent of Congress, ... enter into any Agreement or Compact ... with a foreign Power....” U.S. Const. art. I, \& 10, cl. 3.

nor shall any person holding any office of profit or trust under the united states, or any of them, accept of any present, emolument, office, or title of any kind whatever, from any king, prince or foreign state;

"[A]nd no Person holding any Office of Profit or Trust under them, shall, without the Consent of the Congress, accept of any present, Emolument, Office, or Title, of any kind whatever, from any King, Prince, or foreign State." U.S. CoNST. art. I, \& 9, cl. 8.

nor shall the united states, in congress assembled, or any of them, grant any title of nobility. 
"No Title of Nobility shall be granted by the United States." U.S. Const. art. I, $\S 9$, cl. 8. "No State shall . . grant any Title of Nobility." U.S. Const. art. I, \& 10, cl. 1.

[2] No two or more states shall enter into any treaty, confederation, or alliance whatever between them, without the consent of the united states, in congress assembled, specifying accurately the purposes for which the same is to be entered into, and how long it shall continue.

"No State shall, without the Consent of Congress ... enter into any Agreement or Compact with another State ...." U.S. Const. art. I, $\S 10, \mathrm{cl}$. 3 .

No State shall lay any imposts or duties, which may interfere with any stipulations in treaties, entered into by the united States in congress assembled, with any king, prince, or State, in pursuance of any treaties already proposed by congress, to the courts of France and Spain.

"No State shall, without the Consent of the Congress, lay any Imposts or Duties on Imports or Exports, except what may be absolutely necessary for executing it's inspection Laws: and the net Produce of all Duties and Imposts, laid by any State on Imports or Exports, shall be for the Use of the Treasury of the United States; and all such Laws shall be subject to the Revision and Controul of the Congress." U.S. Const. art. I, \& 10, cl. 2. "No State shall, without the Consent of Congress, lay any Duty of Tonnage ...." U.S. Const. art. I, \& 10, cl. 3.

[3] No vessels of war shall be kept up in time of peace, by any state, except such number only, as shall be deemed necessary by the united states, in congress assembled, for the defence of such state, or its trade;

"No State shall, without the Consent of Congress, ... keep Troops, or Ships of War in time of Peace...." U.S. Const. art. I, \& 10, cl. 3.

nor shall any body of forces be kept up, by any state, in time of peace, except such number only as, in the judgment of the united states, in congress assembled, shall be deemed requisite to garrison the forts necessary for the defence of such state;

"No State shall, without the Consent of Congress, ... keep Troops, in time of Peace...." U.S. CoNsT. art. I, \& 10, cl. 3.

but every state shall always keep up a well regulated and disciplined militia, sufficiently armed and accounted, and shall provide and constantly have ready for use, in public stores, a due number of field pieces and tents, and a proper quantity of arms, ammunition, and camp equipage. 


\section{No comparable provision in the text of the Constitution.}

[4] No State shall engage in any war without the consent of the united States in congress assembled, unless such State be actually invaded by enemies, or shall have received certain advice of a resolution being formed by some nation of Indians to invade such State, and the danger is so imminent as not to admit of a delay till the united states in congress assembled, can be consulted:

"No State shall, without the Consent of Congress, . . . engage in War, unless actually invaded, or in such imminent Danger as will not admit of delay." U.S. CoNsT. art. I, \& 10, cl. 3.

nor shall any state grant commissions to any ships or vessels of war, nor letters of marque or reprisal, except it be after a declaration of war by the united states in congress assembled, and then only against the kingdom or State, and the subjects thereof, against which war has been so declared, and under such regulations as shall be established by the united states in congress assembled, unless such state be infested by pirates, in which case vessels of war may be fitted out for that occasion, and kept so long as the danger shall continue, or until the united states in congress assembled shall determine otherwise.

"No State shall ... grant Letters of Marque and Reprisal ...." U.S. Const. art. I, § 10, cl. 1.

VII. When land forces are raised by any state, for the common defence, all officers of or under the rank of colonel, shall be appointed by the legislature of each state respectively by whom such forces shall be raised, or in such manner as such state shall direct, and all vacancies shall be filled up by the state which first made appointment.

No comparable provision in the text of the Constitution.

VIII. All charges of war, and all other expenses that shall be incurred for the common defence or general welfare, and allowed by the united states in congress assembled, shall be defrayed out of a common treasury, which shall be supplied by the several states, in proportion to the value of all land within each state, granted to or surveyed for any Person, as such land and the buildings and improvements thereon shall be estimated, according to such mode as the united states, in congress assembled, shall, from time to time, direct and appoint.

No comparable provision in the text of the Constitution.

The taxes for paying that proportion shall be laid and levied by the authority and direction of the legislatures of the several states 
within the time agreed upon by the united states in congress assembled.

No comparable provision in the text of the Constitution.

IX. [1] The united states, in congress assembled, shall have the sole and exclusive right and power of determining on peace and war, except in the cases mentioned in the sixth article

"The Congress shall have Power... To declare War ...." U.S. Const. art. I, $\& 8$, cl. 11.

-of sending and receiving ambassadors

"[The President] shall nominate, and by and with the Advice and Consent of the Senate, shall appoint Ambassadors, other public Ministers and Consuls...." U.S. Const. art. II, \& 2, cl. 2. "[The President] shall receive Ambassadors and other public Ministers ...." U.S. CONST. art. II, $\S 3$.

- entering into treaties and alliances,

"[The President] shall have Power, by and with the Advice and Consent of the Senate, to make Treaties, provided two thirds of the Senators present concur." U.S. CONST. art. II, \& 2, cl. 2.

provided that no treaty of commerce shall be made, whereby the legislative power of the respective states shall be restrained from imposing such imposts and duties on foreigners, as their own people are subjected to,

"[A]ll Duties, Imposts and Excises shall be uniform throughout the United States." U.S. Const. art. I, \& 8, cl. 1.

or from prohibiting the exportation or importation of any species of goods or commodities whatsoever

No comparable provision in the text of the Constitution. Note: Congress regularly prohibits importation of goods (e.g., illegal drugs) and exports of goods (e.g., certain weapons and technologies). But the Constitution did contain this provision: "The Migration or Importation of such Persons as any of the States now existing shall think proper to admit, shall not be prohibited by the Congress prior to the Year one thousand eight hundred and eight, but a Tax or duty may be imposed on such Importation, not exceeding ten dollars for each Person." U.S. CONST. art. I, $\& 9$, cl. 1.

-of establishing rules for deciding, in all cases, what captures on land or water shall be legal, and in what manner prizes taken by land or naval forces in the service of the united Sates, shall be divided or appropriated 
"The Congress shall have Power ... To . . make Rules concerning Captures on Land and Water." U.S. CoNST. art. I, $\S 8, c l .11$.

-of granting letters of marque and reprisal in times of peace

"The Congress shall have Power ... To . . grant Letters of Marque and Reprisal." U.S. CONST. art. I, § 8, cl. 11.

-appointing courts for the trial of piracies and felonies committed on the high seas; and establishing courts; for receiving and determining finally appeals in all cases of captures; provided that no member of congress shall be appointed a judge of any of the said courts.

"Congress shall have Power... To define and punish Piracies and Felonies committed on the high Seas ...." U.S. Const. art. I, \& 8, cl. 10. "The judicial Power shall extend to all Cases, in Law and Equity, arising under this Constitution, the Laws of the United States, and Treaties made ...." U.S. CoNsT. art. III, $\S 2$, cl. 1. "[N]o Person holding any Office under the United States, shall be a Member of either House during his Continuance in Office." U.S. Const. art. I, $\$ 6$, cl. 2.

[2] The united states, in congress assembled shall also be the last resort on appeal, in all disputes and differences now subsisting, or that hereafter may arise between two or more states concerning boundary, jurisdiction, or any other cause whatever;

"The judicial Power shall extend to all Cases, in Law and Equity, ... to Controversies between two or more States." U.S. CONST. art. III, $\& 2, c l .1$.

which authority shall always be exercised in the manner following. Whenever the legislative or executive authority, or lawful agent of any state in controversy with another, shall present a petition to congress, stating the matter in question, and praying for a hearing, notice thereof shall be given, by order of congress, to the legislative or executive authority of the other state in controversy, and a day assigned for the appearance of the parties by their lawful agents, who shall then be directed to appoint, by joint consent, commissioners or judges to constitute a court for hearing and determining the matter in question: but if they cannot agree, congress shall name three persons out of each of the united states, and from the list of such persons each party shall alternately strike out one, the petitioners beginning, until the number shall be reduced to thirteen; and from that number not less than seven, nor more than nine names, as congress shall direct, shall, in the presence of congress, be drawn out by lot, and the persons whose names shall be so drawn, or any five of them, shall be commissioners or judges, to hear and finally determine the controversy, so always as 
a major part of the judges, who shall hear the cause, shall agree in the determination: and if either party shall neglect to attend at the day appointed, without showing reasons which congress shall judge sufficient, or being present, shall refuse to strike, the congress shall proceed to nominate three persons out of each State, and the secretary of congress shall strike in behalf of such party absent or refusing; and the judgement and sentence of the court, to be appointed in the manner before prescribed, shall be final and conclusive; and if any of the parties shall refuse to submit to the authority of such court, or to appear or defend their claim or cause, the court shall nevertheless proceed to pronounce sentence, or judgement, which shall in like manner be final and decisive; the judgement or sentence and other proceedings being in either case transmitted to congress, and lodged among the acts of congress, for the security of the parties concerned: provided that every commissioner, before he sits in judgement, shall take an oath to be administered by one of the judges of the supreme or superior court of the State where the cause shall be tried, "well and truly to hear and determine the matter in question, according to the best of his judgement, without favour, affection, or hope of reward:

"In all Cases ... in which a State shall be Party, the supreme Court shall have original Jurisdiction.” U.S. Const. art. III, $\S 2$, cl. 2.

"provided, also, that no State shall be deprived of territory for the benefit of the united states.

"The Congress shall have Power to dispose of and make all needful Rules and Regulations respecting the Territory or other Property belonging to the United States; and nothing in this Constitution shall be so construed as to Prejudice any Claims of the United States, or of any particular State." U.S. Const. art. IV, $\$ 3$, cl. 2.

[3] All controversies concerning the private right of soil claimed under different grants of two or more states, whose jurisdictions as they may respect such lands, and the states which passed such grants are adjusted, the said grants or either of them being at the same time claimed to have originated antecedent to such settlement of jurisdiction, shall, on the petition of either party to the congress of the united states, be finally determined, as near as may be, in the same manner as is before prescribed for deciding disputes respecting territorial jurisdiction between different states.

No comparable provision in the text of the Constitution.

[4] The united states, in congress assembled, shall also have the sole and exclusive right and power of regulating the alloy and value of coin struck by their own authority, or by that of the respective states 
"Congress shall have Power... To coin Money, regulate the Value thereof, and of foreign Coin ...." U.S. Const. art. I, \& 8, cl. 5. "No State shall ... coin Money." U.S. Const. art. I, § 10, cl. 1.

- fixing the standard of weights and measures throughout the united states

"Congress shall have Power ... To ... fix the Standard of Weights and Measures." U.S. Const. art. I, \& 8, cl. 5.

-regulating the trade and managing all affairs with the Indians, not members of any of the states; provided that the legislative right of any state, within its own limits, be not infringed or violated

"Congress shall have Power... To regulate Commerce ... with the Indian Tribes." U.S. Const. art. I, \& 8, cl. 3.

-establishing and regulating post-offices from one state to another, throughout all the united states, and exacting such postage on the papers passing through the same, as may be requisite to defray the expenses of the said office

"Congress shall have Power... To establish Post Offices and post Roads." U.S. CONST. art. I, \& 8, cl. 7.

-appointing all officers of the land forces in the service of the united States, excepting regimental officers

"[The President] ... shall appoint ... all other Officers of the United States, whose Appointments are not herein otherwise provided for, and which shall be established by Law: but the Congress may by Law vest the Appointment of such inferior Officers, as they think proper, in the President alone, in the Courts of Law, or in the Heads of Departments." U.S. CoNST. art. II, \& 2, cl. 2.

-appointing all the officers of the naval forces, and commissioning all officers whatever in the service of the united states;

"[The President] . . . shall appoint ... all other Officers of the United States, whose Appointments are not herein otherwise provided for, and which shall be established by Law: but the Congress may by Law vest the Appointment of such inferior Officers, as they think proper, in the President alone, in the Courts of Law, or in the Heads of Departments." U.S. CoNsT. art. II, \& 2, cl. 2.

making rules for the government and regulation of the said land and naval forces, and directing their operations.

"The Congress shall have Power ... To make Rules for the Government and Regulation of the land and naval Forces." U.S. CONST. art. I, \& 8, cl. 14. 
[5] The united States, in congress assembled, shall have authority to appoint a committee, to sit in the recess of congress, to be denominated, "A Committee of the States," and to consist of one delegate from each State;

"The executive Power shall be vested in a President of the United States of America." U.S. CoNST. art. II, $\$ 1$, cl. 1.

and to appoint such other committees and civil officers as may be necessary for managing the general affairs of the united states under their direction

"The President shall have Power to fill up all Vacancies that may happen during the Recess of the Senate, by granting Commissions which shall expire at the End of their next Session." U.S. CONST. art. II, \&2, cl. 3 .

- to appoint one of their number to preside; provided that no person be allowed to serve in the office of president more than one year in any term of three years;

"[The President] shall hold his Office during the Term of four Years ..." U.S. Const. art. II, $\& 1, \mathrm{cl} .1$.

to ascertain the necessary sums of money to be raised for the service of the united states, and to appropriate and apply the same for defraying the public expenses;

"The Congress shall have Power ... to pay the Debts and provide for the common Defence and general Welfare of the United States." U.S. Const. art. I, $\& 8, \mathrm{cl} .1$.

to borrow money or emit bills on the credit of the united states, transmitting every half year to the respective states an account of the sums of money so borrowed or emitted,

"The Congress shall have Power... To borrow Money on the credit of the United States." U.S. Const. art. I, \& 8, cl. 2.

- to build and equip a navy

"The Congress shall have Power... To provide and maintain a Navy." U.S. Const. art I. $\& 8$, cl. 13.

- to agree upon the number of land forces, and to make requisitions from each state for its quota, in proportion to the number of white inhabitants in such state, which requisition shall be binding; and thereupon the legislature of each state shall appoint the regimental officers, raise the men, and clothe, arm, and equip them, in a soldierlike manner, at the expense of the united states; and the officers and men so clothed, armed, and equipped, shall march to the place appointed, and within the time agreed on by the united states, in con- 
gress assembled; but if the united states, in congress assembled, shall, on consideration of circumstances, judge proper that any state should not raise men, or should raise a smaller number than its quota, and that any other state should raise a greater number of men than the quota thereof, such extra number shall be raised, officered, clothed, armed, and equipped in the same manner as the quota of such state, unless the legislature of such state shall judge that such extra number cannot be safely spared out of the same, in which case they shall raise, officer, clothe, arm, and equip, as many of such extra number as they judge can be safely spared. And the officers and men so clothed, armed, and equipped, shall march to the place appointed, and within the time agreed on by the united states in congress assembled.

The Constitution differs considerably from the Articles of Confederation on this point. Whereas the Articles required the state to provide officers and men to the Continental Army, the Constitution provides that "[t]he Congress shall have Power... To raise and support Armies, but no Appropriation of Money to that Use shall be for a longer Term than two Years." U.S. ConsT. art. I, \& 8, cl. 12.

[6] The united states, in congress assembled, shall never engage in a war, nor grant letters of marque and reprisal in time of peace, nor enter into any treaties or alliances, nor coin money, nor regulate the value thereof nor ascertain the sums and expenses necessary for the defence and welfare of the united states, or any of them, nor emit bills, nor borrow money on the credit of the united states, nor appropriate money, nor agree upon the number of vessels of war to be built or purchased, or the number of land or sea forces to be raised, nor appoint a commander in chief of the army or navy, unless nine states assent to the same,

The Constitution provides that "Congress shall have Power ... To declare War, grant Letters of Marque and Reprisal, and make Rules concerning Captures on Land and Water" without requiring a supermajority of the states to approve. U.S. Const. art. I, \& 8, cl. 11 .

nor shall a question on any other point, except for adjourning from day to day, be determined, unless by the votes of a majority of the united states in congress assembled.

"[A] Majority of each [House] shall constitute a Ouorum to do Business; but a smaller Number may adjourn from day to day . . .." U.S. CONST. art. I, $\$ 5$, cl. 1 .

[7] The congress of the united states shall have power to adjourn to any time within the year, and to any place within the united states, 
so that no period of adjournment be for a longer duration than the space of six Months,

"Neither House, during the Session of Congress, shall, without the Consent of the other, adjourn for more than three days, nor to any other Place than that in which the two Houses shall be sitting." U.S. CONST. art. I, $\& 5$, cl. 4.

and shall publish the Journal of their proceedings monthly, except such parts thereof relating to treaties, alliances, or military operations, as in their judgement require secrecy;

"Each House shall keep a Journal of its Proceedings, and from time to time publish the same, excepting such Parts as may in their Judgment require Secrecy." U.S. CoNST. art. I, \& 5, cl. 3.

and the yeas and nays of the delegates of each State, on any question, shall be entered on the Journal, when it is desired by any delegate; and the delegates of a State, or any of them, at his or their request, shall be furnished with a transcript of the said Journal, except such parts as are above excepted, to lay before the legislatures of the several states.

"[A]nd the Yeas and Nays of the Members of either House on any question shall, at the Desire of one fifth of those Present, be entered on the Journal." U.S. CONST. art. I, \& 5, cl. 3.

$\mathrm{X}$. The committee of the states, or any nine of them, shall be authorized to execute, in the recess of congress, such of the powers of congress as the united states, in congress assembled, by the consent of nine states, shall, from time to time, think expedient to vest them with; provided that no power be delegated to the said committee, for the exercise of which, by the articles of confederation, the voice of nine states, in the congress of the united states assembled, is requisite.

No comparable provision in the text of the Constitution.

XI. Canada acceding to this confederation, and joining in the measures of the united states, shall be admitted into, and entitled to all the advantages of this union;

No comparable provision in the text of the Constitution.

but no other colony shall be admitted into the same, unless such admission be agreed to by nine states.

"New States may be admitted by the Congress into this Union." U.S. Const. art. IV, $\& 3$, cl. 1 .

XII. All bills of credit emitted, monies borrowed, and debts contracted by or under the authority of congress, before the assembling of the united states, in pursuance of the present confederation, shall be 
deemed and considered as a charge against the united States, for payment and satisfaction whereof the said united states and the public faith are hereby solemnly pledged.

"All Debts contracted and Engagements entered into, before the Adoption of this Constitution, shall be as valid against the United States under this Constitution, as under the Confederation." U.S. Const. art. VI, $\& 1$.

XIII. [1] Every State shall abide by the determinations of the united states, in congress assembled, on all questions which by this confederation are submitted to them.

"[T]he Laws of the United States which shall be made in Pursuance [of the Constitution]; and all Treaties made, or which shall be made, under the Authority of the United States, shall be the supreme Law of the Land; and the Judges in every State shall be bound thereby, any Thing in the Constitution or Laws of any state to the Contrary notwithstanding." U.S. CONST. art. VI, \&2.

And the Articles of this confederation shall be inviolably observed by every state,

"This Constitution. . . shall be the supreme Law of the Land; and the Judges in every State shall be bound thereby, any Thing in the Constitution or Laws of any state to the Contrary notwithstanding." U.S. CONST. art. VI, $\S 2$.

and the union shall be perpetual;

No comparable provision in the text of the Constitution.

nor shall any alteration at any time hereafter be made in any of them, unless such alteration be agreed to in a congress of the united states, and be afterwards con-firmed by the legislatures of every state.

"The Congress, whenever two thirds of both Houses shall deem it necessary, shall propose Amendments to this Constitution, or, on the Application of the Legislatures of two thirds of the several States, shall call a Convention for proposing Amendments, which, in either Case, shall be valid to all Intents and Purposes, as Part of this Constitution, when ratified by the Legislatures of three fourths of the several States, or by Conventions in three fourths thereof, as the one or the other Mode of Ratification may be proposed by the Congress; Provided that no Amendment which may be made prior to the Year One thousand eight hundred and eight shall in any Manner affect the first and fourth Clauses in the Ninth Section of the first Article; and that no State, without its Consent, shall be deprived of its equal Suffrage in the Senate." U.S. CONST. art. V. 
[2] And Whereas it hath pleased the Great Governor of the World to incline the hearts of the legislatures we respectively represent in congress, to approve of, and to authorize us to ratify the said articles of confederation and perpetual union,

No comparable provision in the text of the Constitution.

Know Ye, that we, the undersigned delegates, by virtue of the power and authority to us given for that purpose, do, by these presents, in the name and in behalf of our respective constituents, fully and entirely ratify and confirm each and every of the said articles of confederation and perpetual union, and all and singular the matters and things therein contained.

"The Ratification of the Conventions of nine States, shall be sufficient for the Establishment of this Constitution between the States so ratifying the Same." U.S. CoNST. art. VII.

And we do further solemnly plight and engage the faith of our respective constituents, that they shall abide by the determinations of the united states in congress assembled, on all questions, which by the said confederation are submitted to them. And that the articles thereof shall be inviolably observed by the states we respectively represent, and that the union shall be perpetual.

No comparable provision in the text of the Constitution.

In Witness whereof, we have hereunto set our hands, in Congress. Done at Philadelphia, in the State of Pennsylvania, the ninth Day of July, in the Year of our Lord one Thousand seven Hundred and Seventy eight, and in the third year of the Independence of America.

"DJone in Convention by the Unanimous Consent of the States present the Seventeenth Day of September in the Year of our Lord one thousand seven hundred and Eighty seven and of the Independence of the United States of America the Twelfth. In witness whereof We have hereunto subscribed our Names." U.S. CONST. 


\section{Appendix B: Table of Constitutional Provisions and Related Provisions in the Articles of Confederation}

The following table lists all of the provisions of the Constitution (up to the Twelfth Amendment) in Roman type on the left and related provisions in the Articles of Confederation in italics on the right. See Appendix A for the text of the Articles of Confederation.

Preamble: Art. I; Art. III.

Art. I, § 1: No comparable provision.

Art. I, § 2, cl. 1: No comparable provision.

Art. I, § 2, cl. 2: No comparable provision.

Art. I, § 2, cl. 3: Art. V, para. 2.

Art. I, $\S 2$, cl. 4: No comparable provision.

Art. I, § 2, cl. 5: No comparable provision.

Art. I, § 3, cl. 1: Art. V, paras. 1, 2, 4.

Art. I, § 3, cl. 2: Art. V, para. 1.

Art. I, § 3, cl. 3: No comparable provision.

Art. I, § 3, cl. 4: Art. IX, para. 5.

Art. I, $\S 3$, cl. 5: No comparable provision.

Art. I, § 3, cl. 6: No comparable provision.

Art. I, § 3, cl. 7: No comparable provision.

Art. I, § 4, cl. 1: Art. V, para. 1.

Art. I, § 4, cl. 2: Art. V, para. 1.

Art. I, § 5, cl. 1: Art. IX, para. 5.

Art. I, § 5, cl. 2: No comparable provision.

Art. I, § 5, cl. 3: Art. IX, para. 7.

Art. I, $\S 5$, cl. 4: Art. IX, para. 7.

Art. I, § 6, cl. 1: Art. V, paras. 3, 5 .

Art. I, § 6, cl. 2: Art. V, para. 2; Art. IX, para. 1.

Art. I, § 7, cl. 1: No comparable provision.

Art. I, $\S 7$, cl. 2: Art. IX, para. 6.

Art. I, § 7, cl. 3: Art. IX, para. 6.

Art. I, § 8, cl. 1: Art. IX, paras. 1, 5.

Art. I, $\S 8$, cl. 2: Art. IX, paras. 5, 6.

Art. I, § 8, cl. 3: Art. IX, paras. 1, 4.

Art. I, $\S 8$, cl. 4: No comparable provision.

Art. I, $\S 8$, cl. 5: Art. IX, para. 4.

Art. I, § 8, cl. 6: Art. IX, para. 4.

Art. I, § 8, cl. 7: Art. IX, para. 4.

Art. I, § 8, cl. 8: No comparable provision.

Art. I, § 8, cl. 9: Art. IX, paras. 1, 2. 
Art. I, § 8, cl. 10: Art. IX, para. 1.

Art. I, § 8, cl. 11: Art. IX, paras. 1, 6.

Art. I, § 8, cl. 12: Art. IX, paras. 5, 6 .

Art. I, § 8, cl. 13: Art. IX, paras. 5, 6 .

Art. I, § 8, cl. 14: Art. IX, para. 4.

Art. I, $\S 8$, cl. 15: Art. III; Art. XI, para. 5.

Art. I, § 8, cl. 16: Art. VI, para. 4; Art. VII; Art. XI, para. 5.

Art. I, § 8, cl. 17: Art. XI, para. 7.

Art. I, § 8, cl. 18: No comparable provision.

Art. I, § 9, cl. 1: Art. IX, para. 1.

Art. I, § 9, cl. 2: No comparable provision.

Art. I, § 9, cl. 3: No comparable provision.

Art. I, § 9, cl. 4: Art. VIII.

Art. I, § 9, cl. 5: No comparable provision.

Art. I, § 9, cl. 6: Art. IV, para. 1 .

Art. I, § 9, cl. 7: Art. VIII; Art. IX, para. 5.

Art. I, § 9, cl. 8: Art. VI, para. 1.

Art. I, § 10, cl. 1: Art. VI, paras. 1, 5; Art. IX, para. 4.

Art. I, § 10, cl. 2: Art. VI, para. 3.

Art. I, § 10, cl. 3: Art. VI, paras. 2, 4, 5.

Art. II, § 1, cl. 1: Art. IX, para. 5; Art. X.

Art. II, § 1, cl. 2: Art. IX, para. 5.

Art. II, § 1, cl. 3: Art. IX, para. 5.

Art. II, § 1, cl. 4: No comparable provision.

Art. II, § 1, cl. 5: No comparable provision.

Art. II, § 1, cl. 6: No comparable provision.

Art. II, § 1, cl. 7: No comparable provision.

Art. II, § 1, cl. 8: No comparable provision.

Art. II, § 2, cl. 1: Art. IX, para. 6.

Art. II, § 2, cl. 2: Art. IX, paras. 1, 4.

Art. II, § 2, cl. 3: Art. X.

Art. II, § 3: No comparable provision.

Art. III, § 1: No comparable provision.

Art. III, § 2, cl. 1: Art. IX, paras. 1, 2.

Art. III, § 2, cl. 2: Art. IX, para. 2.

Art. III, § 2, cl. 3: No comparable provision.

Art. III, § 3, cl. 1: No comparable provision.

Art. III, § 3, cl. 2: No comparable provision.

Art. IV, § 1: Art. IV, para. 3.

Art. IV, § 2, cl. 1: Art. IV, para. 1.

Art. IV, § 2, cl. 2: Art. IV, paras. 1, 2. 
Art. IV, § 2, cl. 3: Art. IV, para. 1.

Art. IV, § 3, cl. 1: Art. XI.

Art. IV, § 3, cl. 2: Art. IX, para. 2.

Art. IV, § 4: No comparable provision.

Art. V: Art. XIII, para. 1.

Art. VI, cl. 1: Art. XII.

Art. VI, cl. 2: Art. XIII, para. 1.

Art. VI, cl. 3: No comparable provision.

Art. VII: Art. XIII, para. 2.

Amend. I: No comparable provision.

Amend. II: Art. VI, para. 3.

Amend. III: No comparable provision.

Amend. IV: No comparable provision.

Amend. V: No comparable provision.

Amend. VI: No comparable provision.

Amend. VII: No comparable provision.

Amend. VIII: No comparable provision.

Amend. IX: No comparable provision.

Amend. X: Art. II.

Amend. XI: No comparable provision.

Amend. XII: Art. IX, para. 5. 